\title{
Recent Advances in Mycotoxin Determination for Food Monitoring via Microchip
}

\author{
Yan Man 1,2,3, Gang Liang 1,2,3, An Li 1,2,3 and Ligang Pan 1,2,3,* \\ 1 Beijing Research Center for Agricultural Standards and Testing, Beijing Academy of Agriculture and \\ Forestry Sciences, Beijing 100097, China; manyan3669@163.com (Y.M.); liangg@brcast.org.cn (G.L.); \\ lia@brcast.org.cn (A.L.) \\ 2 Risk Assessment Lab for Agro-products, Ministry of Agriculture of the People's Republic of China, \\ Beijing 100125, China \\ 3 Beijing Municipal Key Laboratory of Agriculture Environment Monitoring, Beijing 100097, China \\ * Correspondence: panligang@126.com; Tel.: +86-105-150-3013
}

Academic Editors: Michelangelo Pascale and Maria C. DeRosa

Received: 12 September 2017; Accepted: 9 October 2017; Published: 14 October 2017

\begin{abstract}
Mycotoxins are one of the main factors impacting food safety. Mycotoxin contamination has threatened the health of humans and animals. Conventional methods for the detection of mycotoxins are gas chromatography (GC) or liquid chromatography (LC) coupled with mass spectrometry (MS), or enzyme-linked immunosorbent assay (ELISA). However, all these methods are time-consuming, require large-scale instruments and skilled technicians, and consume large amounts of hazardous regents and solvents. Interestingly, a microchip requires less sample consumption and short analysis time, and can realize the integration, miniaturization, and high-throughput detection of the samples. Hence, the application of a microchip for the detection of mycotoxins can make up for the deficiency of the conventional detection methods. This review focuses on the application of a microchip to detect mycotoxins in foods. The toxicities of mycotoxins and the materials of the microchip are firstly summarized in turn. Then the application of a microchip that integrates various kinds of detection methods (optical, electrochemical, photo-electrochemical, and label-free detection) to detect mycotoxins is reviewed in detail. Finally, challenges and future research directions in the development of a microchip to detect mycotoxins are previewed.
\end{abstract}

Keywords: mycotoxin; microchip; microfluidic; microarray

\section{Introduction}

Mycotoxins are a class of ubiquitious toxic compounds produced by the metabolism of certain fungi in food production [1,2]. Over 300 mycotoxins have been recognized and identified [3]. The most common mycotoxins are aflatoxins (AFs), alternaria toxins, ochratoxin A (OTA), deoxynivalenol (DON), zearalenone (ZEA), patulin (PTL), T-2 toxin (T-2), fumonisin B1 (FB1), and citrinin (CIT) [4]. The consumption of these mycotoxin-contaminated foods can cause severe toxic effects on human and animal health due to their mutagenicity, teratogenicity, carcinogenicity, nephrotoxicity, immunosuppression, and so on. They are more dangerous than food additives or pesticide residues [5]. Table 1 summarizes the representative mycotoxins and their toxicities. About $25 \%$ of food crops all over the world are significantly infected by mycotoxins according to the report of the Food and Agriculture Organization of the United Nations [6]. So far, there have been some statutory or guideline limits set for mycotoxins in food and feed by regulatory authorities worldwide; moreover, the regulated mycotoxins, commodities, and the maximum tolerable levels vary widely in different countries [7]. Hence, highly sensitive and reliable determination methods are requested in order to ensure food safety against mycotoxins. 
Currently, numerous methods have been developed for the qualitative analysis of mycotoxins. Among these, liquid chromatography (LC) or gas chromatography (GC) coupled with an ultraviolet detector (UVD) [8,9], fluorescence detector (FLD) [10,11], or diode array detector (DAD) [12,13], or MS based on electrospray ionization (ESI) [14-16] or atmospheric pressure chemical ionization (APCI) [17-19] interfaces are the most common and preferred methods. Additionally, immunoassays are a powerful analytical technique that has been used extensively in the detection of mycotoxins [20-22]. Although these methods have high sensitivity and selectivity, they are laboratory-based, time-consuming, involve high costs, and often require large amounts of hazardous regents and solvents during the process of analysis.

Owing to its miniaturization, integration, automation, and high-throughput, an advanced microchip has attracted a large amount of interest as a rapid assay strategy in the detection of mycotoxins [23,24]. This work provides updated information on the determination of mycotoxins using microchips (both microfluidic chips and microarray chips). The materials used for the fabrication of microchip are briefly commented on. The emerging microchips based on optical detection, electrochemical detection, photo-electrochemical detection, as well as a label-free detection method are emphasized. Finally, the challenges and opportunities of using a microchip for the detection of mycotoxins in foods will be stated shortly.

Table 1. The representative mycotoxins and their toxicities.

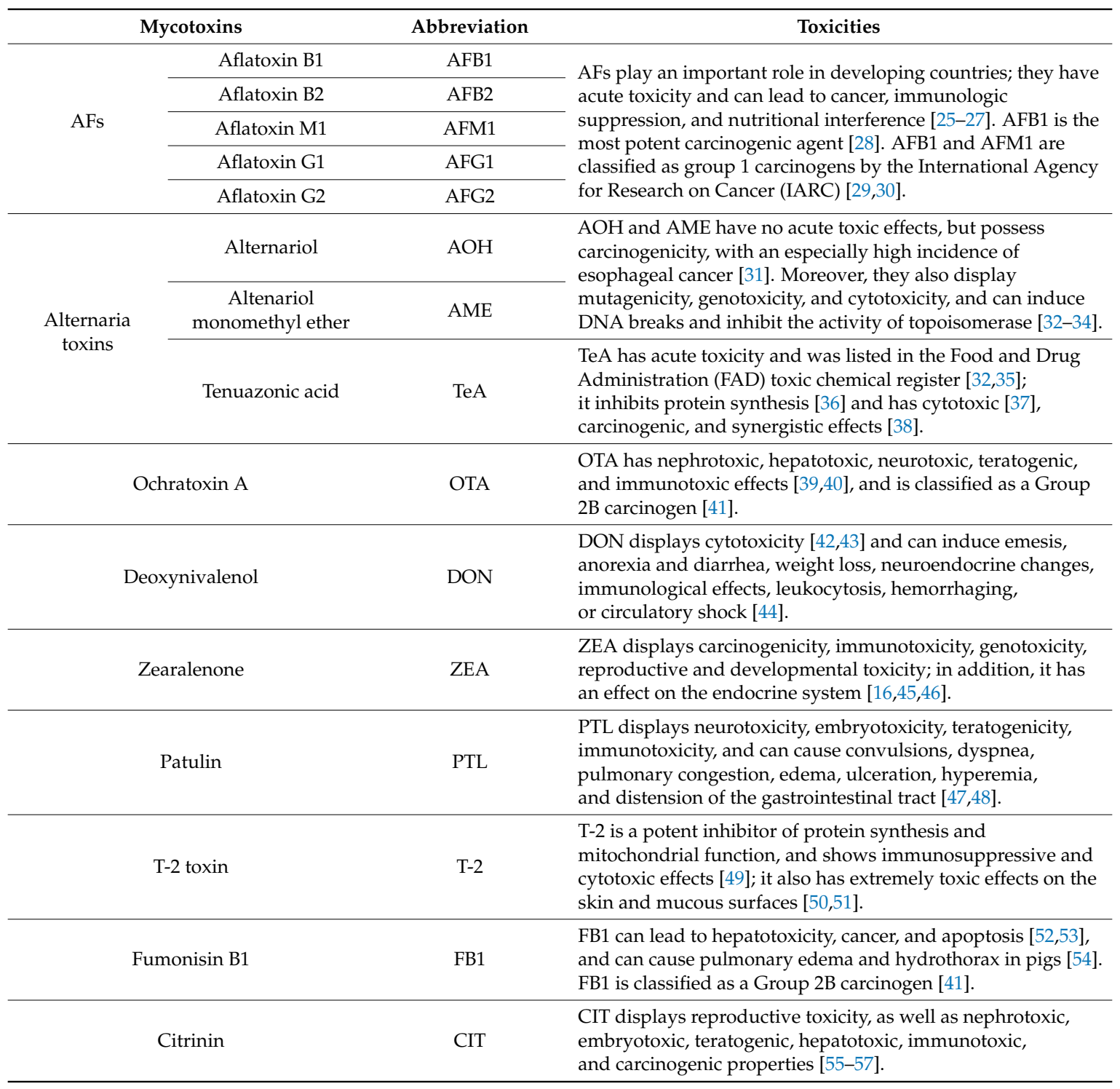




\section{Materials of the Microchip}

Microchips, including microfluidic chips and microarray chips, are a powerful tool for realizing the quantitative analysis of a vast variety of objects with many advantages including high sensitivity, short analysis time, less sample and reagent consumption, high throughput, and low-cost analysis [58-61]. Microfluidic chips are the science and technology of systems that process or manipulate only $10^{-9}$ to $10^{-18}$ L of fluids, using channels with micro-sized dimensions [62-64]. Microarray chips are a two-dimensional arrangement of specific biological probes (DNA, polypeptides, proteins, cells, et al.) deposited in an accessible fashion on a glass slide or other substrate (polymer-coated glass, plastic, etc.) [65]. A vast variety of inorganic materials and polymers were used for the fabrication of microchips. Inorganic materials like silicon and glass are the first-generation materials used for the fabrication of microchips by photolithography and etching technology $[62,66]$. The chips based on silicon or glass substrates are widely used in capillary electrophoresis (CE) due to the stable electroosmotic mobility and high thermoconductivity. The major problem for silicon and glass chips is that the bonding is very difficult in the fabrication process due to the high temperature and super-clean lab environment that are usually required. In addition, the silicon is opaque. Hence, these limitations of the glass or silicon chips promote the development of polymer-based chips. The elastomeric polymer of polydimethylsiloxane (PDMS) has been the predominant polymer material for the preparation of microchips. Compared with glass and silicon chips, PDMS chips could be fabricated with the advantages of low cost, high elasticity, and easy and reversible bonding, and they could also be integrated with micropumps and microvalves. PDMS chips also have notable limitations, such as strong nonspecific adsorption and incompatibility with organic solvents. The other polymer chips were also accompanied by PDMS chips and have been identified as complementary to PDMS with the properties of rapid prototyping, higher rigidity, and better resistance to organic solvents [67]. For instance, rigid plastic polymers, such as poly(methyl methacrylate) (PMMA), polycarbonate (PC), polyimide (PI), polystyrene (PS), poly(vinyl chloride) (PVC), polyethylene terephthalate (PET), cyclic olefin copolymer (COC), teflon perfluoroalkoxy (PFA), and fluorinated ethylenepropylene (FEP) are the other types of materials for the fabrication of microchips. In addition, photosensitive polymers containing Norland optical adhesives (NOA81), SU-8 photoresist, and poly ( $\varepsilon$-caprolactone (CL)-DL-lactide (LA)) (pCLLA) tetraacrylate, as well as hydrogel polymers, such as poly(ethylene glycol) (PEG), were also used for the fabrication of microchips. In recent years, paper substrates, which are widely available and inexpensive, have also been used for the fabrication of microchips. The advantages and disadvantages of the different microchip materials are summarized in Table 2.

Table 2. Representative materials used for the fabrication of microchips.

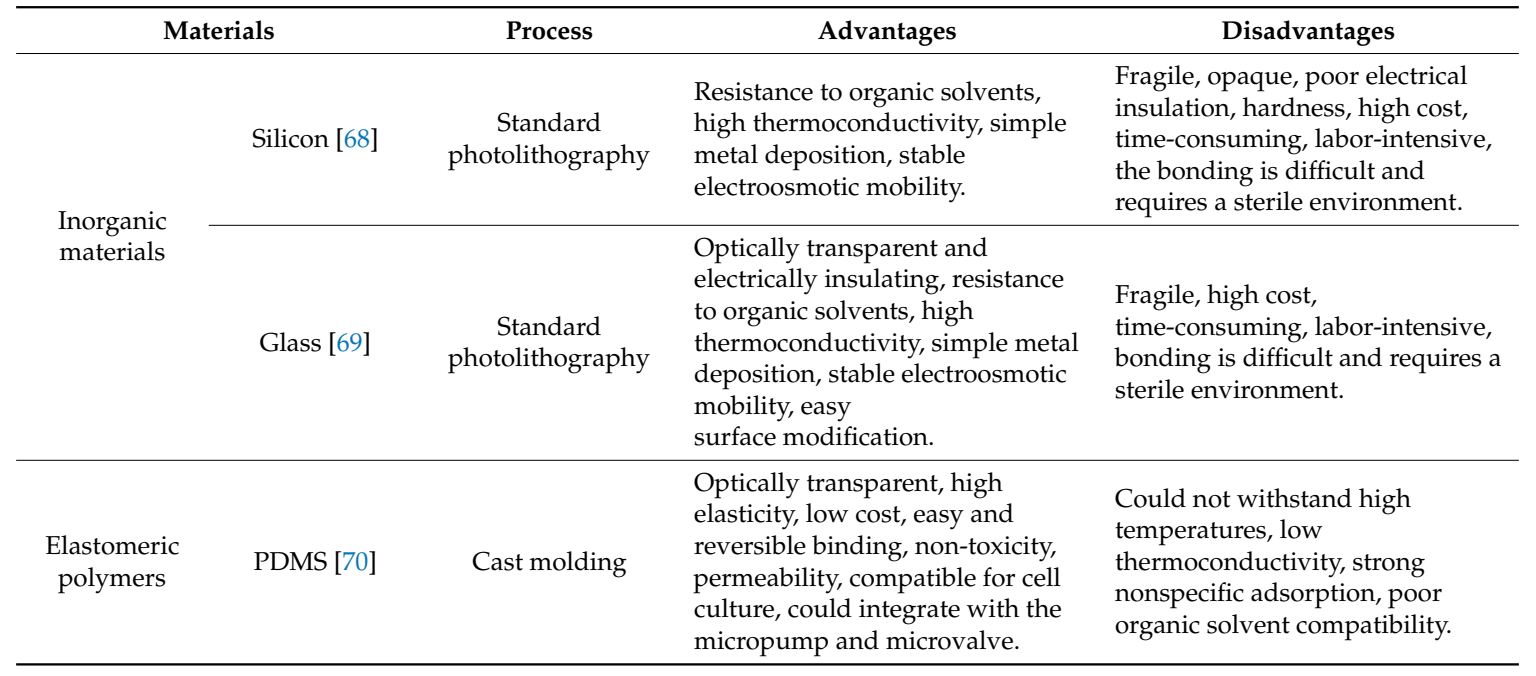


Table 2. Cont.

\begin{tabular}{|c|c|c|c|c|}
\hline Mat & rials & Process & Advantages & Disadvantages \\
\hline \multirow{6}{*}{$\begin{array}{l}\text { Rigid plastic } \\
\text { polymers }\end{array}$} & PMMA [71] & \multirow{6}{*}{ Thermal molding } & \multirow{5}{*}{$\begin{array}{l}\text { Organic solvent compatibility } \\
\text { better than PDMS, low cost, can } \\
\text { produce thousands of replicas at a } \\
\text { high rate, the thermal bonding } \\
\text { does not require a } \\
\text { sterile environment. }\end{array}$} & \multirow{5}{*}{$\begin{array}{l}\text { Poor permeability and heat } \\
\text { conductivity, high rigidity, } \\
\text { difficult surface modification, } \\
\text { cannot withstand high } \\
\text { temperatures. }\end{array}$} \\
\hline & PI [72] & & & \\
\hline & PS [74] & & & \\
\hline & PET [75] & & & \\
\hline & COC [77] & & & \\
\hline & Teflon FEP [78] & & $\begin{array}{l}\text { Extremely inert to chemical } \\
\text { solvents, optically transparent, } \\
\text { moderate permeability, } \\
\text { antifouling, proper mechanical } \\
\text { strength, low nonspecific } \\
\text { absorption, no leaching of residue } \\
\text { molecules from the material bulk } \\
\text { into the solution in the channel. }\end{array}$ & $\begin{array}{l}\text { Melting temperatures are high } \\
\text { (over } 280^{\circ} \mathrm{C} \text { ). }\end{array}$ \\
\hline $\begin{array}{l}\text { Hydrogel } \\
\text { polymers }\end{array}$ & PEG $[79,80]$ & $\begin{array}{l}\text { UV-induced } \\
\text { polymerization }\end{array}$ & $\begin{array}{l}\text { Highly porous with controllable } \\
\text { pore sizes, allowing small } \\
\text { molecules or even } \\
\text { bio-nanoparticles to diffuse } \\
\text { through, compatible for cell } \\
\text { culture, short preparation time. }\end{array}$ & The bonding is difficult. \\
\hline \multirow[b]{2}{*}{$\begin{array}{l}\text { Photosensitive } \\
\text { polymer }\end{array}$} & $\begin{array}{l}\text { SU-8 } \\
\text { photoresist [81] }\end{array}$ & & $\begin{array}{l}\text { Stable even at high temperatures, } \\
\text { resistant to most solvents, } \\
\text { and optically transparent. }\end{array}$ & \multirow[b]{2}{*}{$\begin{array}{l}\text { High cost, high stiffness, } \\
\text { poor permeability, and } \\
\text { non-uniform thickness. }\end{array}$} \\
\hline & NOA81 [82] & Photolithography & $\begin{array}{l}\text { Transparent, rapid, } \\
\text { solvent-resistant, lower } \\
\text { auto-fluorescence, and the } \\
\text { thickness can be easily } \\
\text { manipulated. }\end{array}$ & \\
\hline Paper & Paper [84] & $\begin{array}{l}\text { Lithographic } \\
\text { methods and } \\
\text { printing (cutting) } \\
\text { methods }\end{array}$ & $\begin{array}{l}\text { Portable and low-cost analysis, } \\
\text { without the need for power or } \\
\text { external components; large } \\
\text { surface-to-volume ratio, the } \\
\text { cheapest materials. }\end{array}$ & $\begin{array}{l}\text { Liquids may not be well confined } \\
\text { in the channel due to } \\
\text { hydrophobicity, the applicable } \\
\text { detection methods are relatively } \\
\text { limited, low detection sensitivity, } \\
\text { evaporation of liquid. }\end{array}$ \\
\hline
\end{tabular}

\section{Application of Microchips for the Determination of Mycotoxins in Foods}

The detection methods integrated into microchips are mainly optical detection, electrochemical detection, photo-electrochemical detection, and a label-free detection method. Table 3 summarizes the representative microchips used to detect mycotoxins in food.

\subsection{Optical Detection}

\subsubsection{Fluorescence Detection}

Fluorescence detection has been widely used in the majority of work on microchips due to its excellent sensitivity [85]. In the detection of mycotoxins, Soares et al. [22] developed an integrated PDMS microchip device consisting of two modules in series, an aqueous two-phase extraction (ATPE) module for the simultaneous matrix clean-up, concentration of OTA in red wine and an indirect competitive fluorescence-linked immunosorbent assay module for OTA quantitative detection (Figure 1). The limit of detection (LOD) of OTA spiked in raw red wine was $0.26 \mu \mathrm{g} / \mathrm{L}$. The novel microfluidic chip based on ATPE can deal with complex sample matrices without extra sample pretreatment processes and instruments. The microfluidic chip-based microarray analytical method by fluorescence detection also used for the detection of mycotoxins. Hu et al. [86] prepared a PDMS-glass 
microfluidic chip and formed a smectite-polyacrylamide (PAM) nanocomposite strips microarray on the glass slide by the layer-by-layer assembly method in the PDMS channel, for the rapid fluorometric quantitative detection of AFB1 in corn with an LOD of $6.09 \mu \mathrm{g} / \mathrm{kg}$. Compared with the analysis of microarray chip, this method reduced the detection time, increased detective sensitivity, and enhanced analytical performance due to the parallel multi-channel.

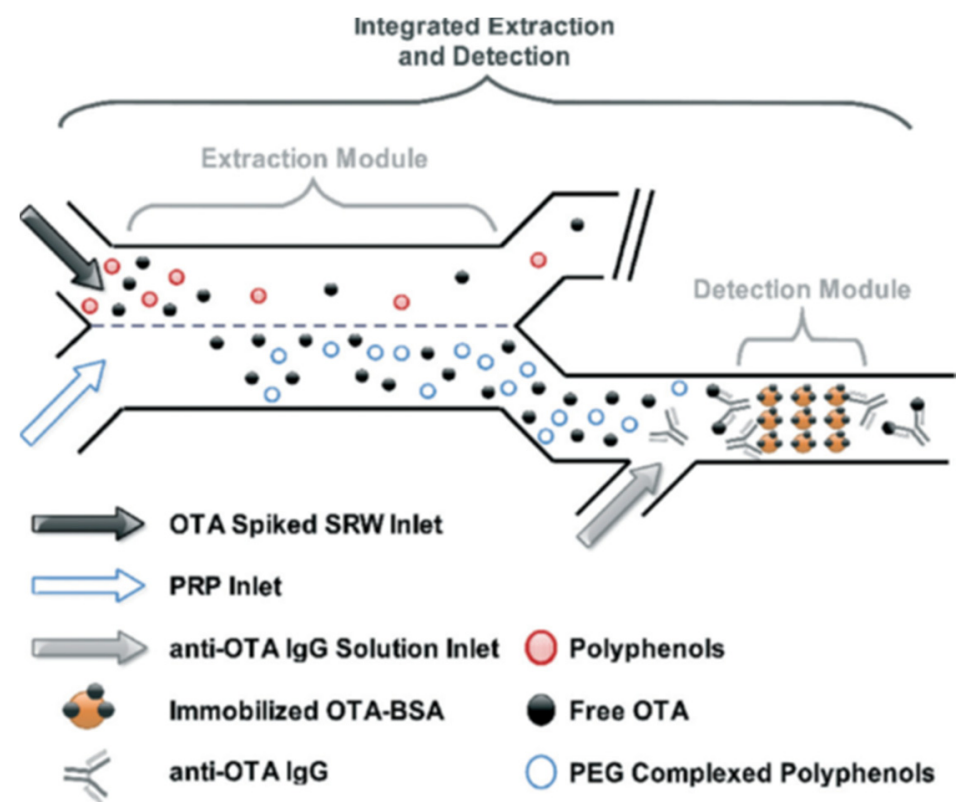

Figure 1. Conceptual schematic of the integrated microfluidic ATPE (aqueous two-phase extraction) strategy for matrix neutralization and OTA (ochratoxin A) concentration in red wine samples [22]. (Reprinted from reference [22], Copyright (2014), with permission from Royal Society of Chemistry).

In general terms, the synthesis of a mycotoxin and carrier protein conjugate is time-consuming, consumes large amounts of expensive organic reagents, and forms randomly crosslinked and unstable molecules, so that can be considered as one major drawback of the competitive immunoassay $[87,88]$. Nevertheless, a mimotope, as an alternative to a mycotoxin-protein conjugate, can be applied to competitive immunoassay. Peltomaa et al. [89] selected a novel mimotope from a commercial peptide library by phage display technology and, furthermore, developed a microarray immunochip using the synthetic derivative of this mimotope for the detection of FB1 in spiked maize and wheat with the LOD of $11.1 \mu \mathrm{g} / \mathrm{L}$ (Figure 2). The mimotope-based immunoassay showed similar or superior sensitivity and reproducibility, reduced analysis time and consumption of toxic reagents, and avoided the chemical synthesis of hapten and a hapten carrier complex. 

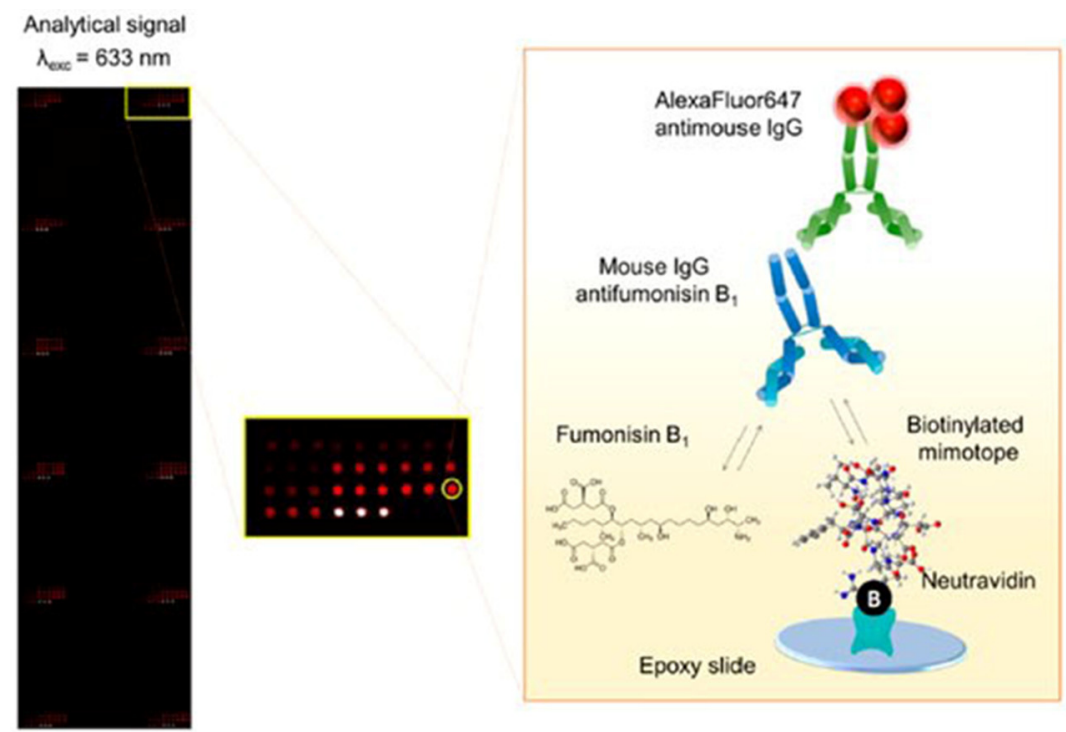

Figure 2. Schematic presentation of the microarray-based immunoassay for fumonisin detection with biotinylated mimotopes [89]. (Reprinted from reference [89], Copyright (2017), with permission from American Chemical Society).

Additionally, considering that a wide variety of mycotoxins have been found in foods, the detection of multiple toxic mycotoxins is of importance in food quality control, so it is urgent to develop multiplexed, high-throughput methods for mycotoxins detection. For instance, Miriam et al. [90,91] developed a competitive microarray immunochip for the simultaneous detection of OTA and DON. Biotinylated OTA and DON were immobilized in arrays onto the NeutrAvidin-functionalized waveguide, respectively. The LODs of OTA by fluorescence detection were 3.8-100 $\mu \mathrm{g} / \mathrm{kg}$ in several cereals, 7 and $38 \mu \mathrm{g} / \mathrm{kg}$ in coffee and wine, respectively, and the LODs of DON were $0.2-50 \mu \mathrm{g} / \mathrm{kg}$ in oats and $4 \mu \mathrm{g} / \mathrm{L}$ in air effluents, respectively. Wang et al. [92] established a protein microarray immunochip for simultaneous and rapid detection of AFB1, AFM1, DON, OTA, T-2, and ZEA mycotoxins in drinking water. Six complete antigens were contact printed and immobilized onto agarose-modified glass chip, and a fluorescence indirect competitive immunoassay was used for the detection. The LODs of AFB1, AFM1, DON, OTA, T-2, and ZEA in drinking water were 0.01, 0.24, $15.45,15.39,0.05$, and $0.01 \mu \mathrm{g} / \mathrm{L}$, respectively.

Furthermore, an aptamer can be used as an alternative to an antibody in the development of biosensors and other analytical methods due to its unique features such as good stability, easy modification, and low-cost production. Yang et al. [93] designed a new high-throughput biochip based on photonic crystal microsphere (PHCM) suspension array for the detection of AFB1, OTA, and FB1 mycotoxins in cereal samples. The hybridization duplex strands of toxin aptamers and their partial complementary strands were immobilized on the surfaces of silica PHCMs. When toxins are present in the sample, the aptamers will specifically bind to their target mycotoxins, the distance between fluorescent dye and quencher increases, and the fluorescence signal recovers. The LODs were $15.96 \times 10^{-6} \mu \mathrm{g} / \mathrm{L}$ for AFB1, $3.96 \times 10^{-6} \mu \mathrm{g} / \mathrm{L}$ for OTA and $0.011 \mu \mathrm{g} / \mathrm{L}$ for FB1.

To conclude, although the abovementioned fluorescence detection methods show good sensitivity and reproducibility, and the labeled molecules are small in size, they require external light sources or the excitation of fluorescent labels, so the integrated optical components are complicated, expensive, large, and bulky. Moreover, the detection signal is also susceptible to interference from scattered light, background fluorescence, and turbidity of samples. 


\subsubsection{Chemiluminescence Detection}

Chemiluminescent detection has been used in the analysis of microchips due to the advantages of low detection limits and wide dynamic ranges, and, compared with fluorescence detection, chemiluminescent detection only requires simple instrument configuration as a result of no external light sources or spectroscopes [94,95]. Sauceda-Friebe [96] developed an indirect competitive immunochip and prepared a fully automated flow through the device with a chemiluminescence readout system for the detection of OTA in green coffee extract. The peptide-linked OTAs were synthesized and covalent immobilized to the epoxy derivatized glass chip surface. The peptide linker provides free amino groups available for the covalent coupling of compounds and supplies a biocompatible space for the target analyte. The chemiluminescence signals were collected with only a CCD camera, and the limit of quantitation (LOQ) of OTA in green coffee extract was $0.3 \mu \mathrm{g} / \mathrm{L}$. Moreover, this method has the potential for on-site detection due to all the steps of experiment being automated. Furthermore, Oswald et al. [97] developed a regenerable, reusable glass microarray chip for the parallel detection of AFB1, AFB2, OTA, DON, and FB1 multiple mycotoxins in oat extracts by a fully automated chemiluminescence microarray readout device. However, the emission intensity of chemiluminescent detection depends on a variety of environmental factors such as temperature, $\mathrm{pH}$, ionic strength, and so on [95]. Hence, the environmental factors should be strictly controlled in the detection process.

\subsubsection{Colorimetric Detection}

Recently, a rapid, portable, and inexpensive detection method without the need for sophisticated instrumentation was developed for mycotoxin detection by visual colorimetric analysis. Liu et al. [98] designed and synthesized an OTA-responsive aptamer-cross-linked hydrogel and used it to fabricate a volumetric bar chart chip (V-chip) for portable and visual quantitative detection of OTA in beer (Figure 3). The OTA responsive hydrogel was prepared by the mixture of OTA aptamer, polymer strands A (P-SA), polymer strands B (P-SB), and platinum nanoparticles (PtNPs). Here, P-SA and P-SB were obtained by grafting short DNA strands A and B onto polyacrylamide polymers. Moreover, the OTA aptamer is complementary to short strands A and B. The OTA in beer was detected by the prepared V-chip, and the LOD was $0.51 \mu \mathrm{g} / \mathrm{kg}$. Ma et al. [99] also applied the same approach for the detection of AFB1 in beer with the LOD of $0.55 \mu \mathrm{g} / \mathrm{kg}$. Thus, the portable, visual, and quantitative detection of a target in real samples can be achieved by a distance-based readout V-chip combined with a target-responsive hydrogel. Additionally, Li et al. [100] developed an integrated smartphone-app-chip (SPAC) system for the quantitation of AFB1 in corn samples with LOD of $3 \mu \mathrm{g} / \mathrm{kg}$. The detection was realized on a transparent plastic chip plate by an indirect competitive immunoassay. A cost-effective 3D-printed optical accessory attached to a smartphone was used to provide uniform illumination for imaging the chip, then the chip images were captured by the smartphone camera and directly processed by an Android app. The SPAC system was suitable for real-time, on-site detecting of AFB1 in foods in China and North America. Colorimetric detection provides high sensitivity, selectivity, low cost, and portability without any large-scale instrument, so it is suitable for rapid, real-time, on-site quantitative detection of mycotoxins to ensure food safety. 

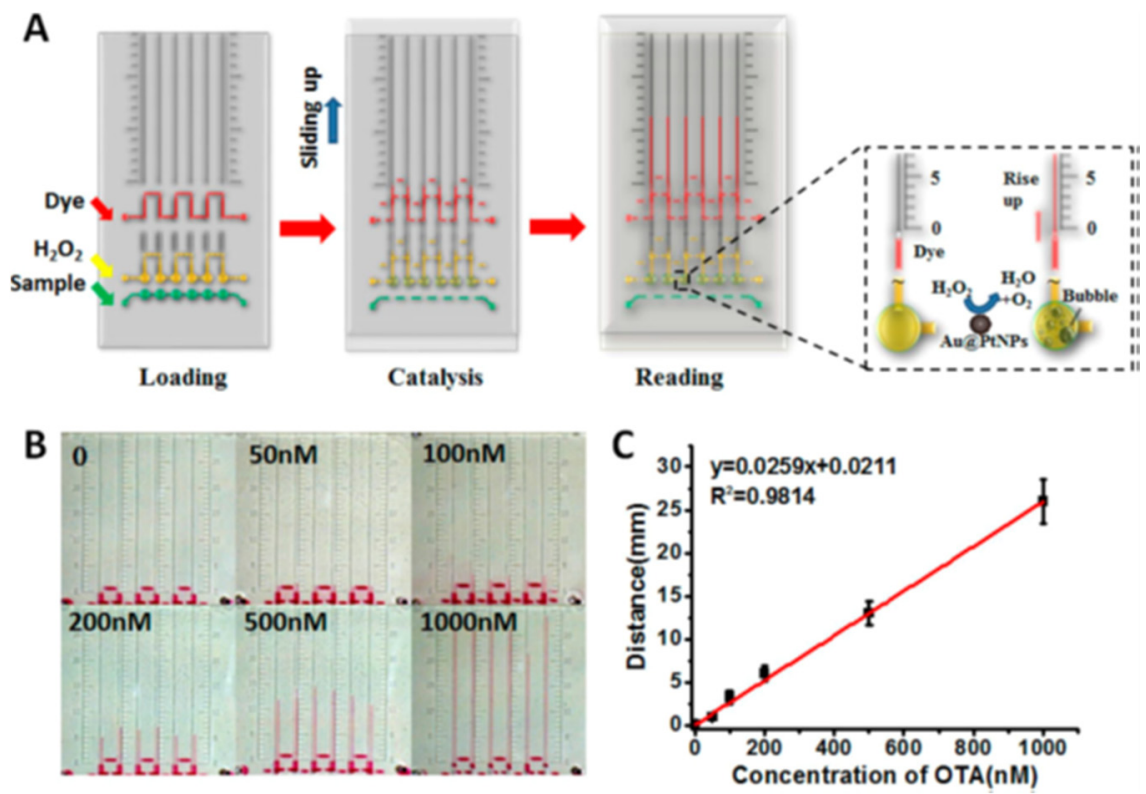

Figure 3. Performance of the HV-Chip for the detection of OTA [98]. (A) Working principle of the target-responsive hydrogel combined with the volumetric bar-chart chip readout for visual quantitative detection. (B) Images showing ink advancement for the detection of OTA in the range of 0 to $1000 \mathrm{nM}$ in $30 \mathrm{~min}$. (C) Linear standard curve was obtained from 0 to 1000 nM OTA. (Reprinted from reference [98], Copyright (2015), with permission from American Chemical Society).

\subsection{Electrochemical Detection}

The properties of high sensitivity and selectivity, the response not being limited by optical path length and sample turbidity, high compatibility, miniaturization, and integration have enabled electrochemical detection method to become an excellent technique to incorporate into microchip devices [101,102]. Piermarini et al. [103] prepared 96-well screen-printed carbon electrodes, and incorporated them in the electrochemical plate. Then the 96-well screen-printed microarray chip was used for an indirect competitive immunoassay by electrochemical detection for the detection of AFB1 in corn. An AFB1-bovine serum albumin (BSA) conjugate was immobilized on the carbon electrodes by physical absorption. The LOD of AFB1 was $0.03 \mu \mathrm{g} / \mathrm{L}$; the working range was 0.05-2 $\mu \mathrm{g} / \mathrm{L}$. For the carbon electrodes, Parker et al. [104] fabricated a gold electrode microarray immunochip by deposition, etching, and lithographic techniques for the detection of AFM1 in milk. AFM1 antibodies were immobilized on the gold microelectrodes by chemical cross-linking with 1,4-phenylene diisothiocyanate. A competitive electrochemical immunoassay was developed on the prepared gold microelectrode surface. The LOD of AFM1 in milk was $0.008 \mu \mathrm{g} / \mathrm{L}$. Compared with abovementioned screen-printed carbon electrodes, the gold microelectrodes can offer a steady-state cyclic voltammogram and a higher sensitivity.

Additionally, a microfluidic immunochip was developed by Arévalo et al. [105] for the detection of CIT in rice by electrochemical detection; CIT-ovalbumin (OVA) conjugates were immobilized on gold disk modified with cysteamine, the LOD of $0.1 \mu \mathrm{g} / \mathrm{L}$ and LOQ of $0.5 \mu \mathrm{g} / \mathrm{L}$ for CIT. Furthermore, the microfluidic chip coupled with gold microelectrode arrays was developed by Olcer [106] and Uludag [107] for real-time electrochemical detection of DON in wheat with a LOD of $6.25 \mu \mathrm{g} / \mathrm{L}$ and AFB1 in foods with a LOD of $0.08-0.65 \mu \mathrm{g} / \mathrm{kg}$ (Figure 4). The novel biochips consisted of six working electrodes with shared references and counter electrodes, and the microfluidic channel was created on the electrode arrays by double-sided sticky tape. The real-time electrochemical microfluidic chip would provide an on-site, rapid, and cost-effective solution for the detection of mycotoxins. 


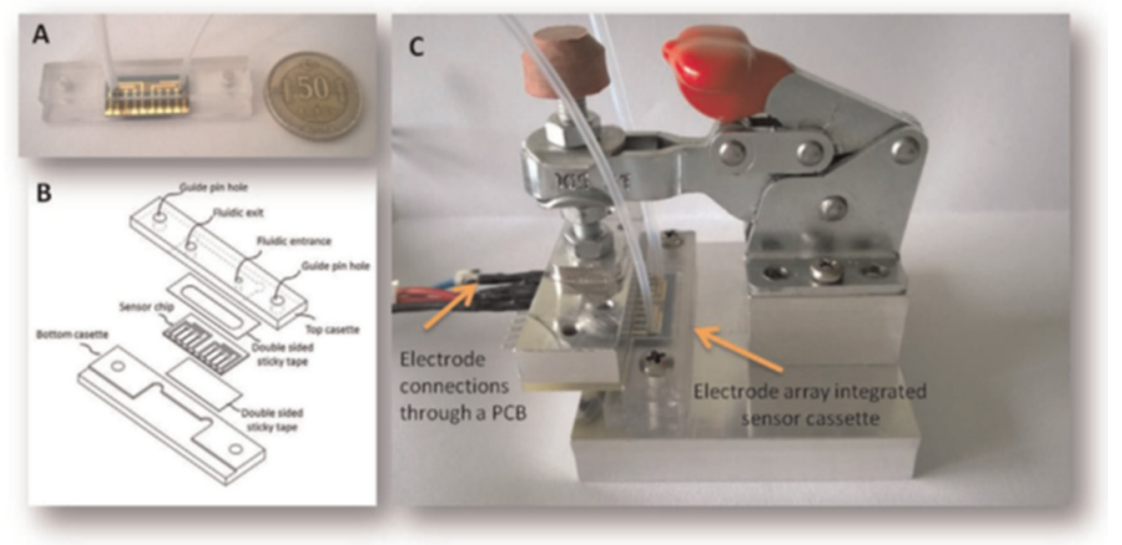

Figure 4. (A) Electrode array integrated sensor cassette. (B) A flow cell is formed and the electrode array is fixed to the sensor cassette by means of a double sided sticky tape. (C) For the laboratory prototype, a printed circuit board (PCB) attached clamp is used to establish electronic connections between the electrode arrays and the potentiostat device [106]. (Reprinted from reference [106], Copyright (2014), with permission from Elsevier).

Electrochemical microfluidic chips coupled with magnetic bead-based immunoassay were also used to determine mycotoxins. Hervás [108,109] and Panini [110] integrated magnetic bead-based electrochemical enzyme-linked immunosorbent assay (ELISA) on microfluidic chips for the determination of ZEA. The ZEA in real samples and HRP-ZEA conjugates compete for the binding sites of anti-ZEA monoclonal antibodies, which were immobilized on protein $G$ modified magnetic beads. The LODs of ZEA in baby foods and feed samples were $0.4-1 \mu \mathrm{g} / \mathrm{L}$. Moreover, this method was also used by Fernández-Baldo for the detection of OTA in apples with a LOD of $50 \mu \mathrm{g} / \mathrm{kg}$ [111]. Here, magnetic beads acted as antibody immobilization carriers and the mobile substrates in microfluidic chips can be easily handled and manipulated by an external magnet. Moreover, due to the use of magnetic beads, the performance of the immunoassay was improved as a result of the increased surface-to-volume ratio.

\subsection{Photo-Electrochemical Detection}

Photosensors, especially those based on hydrogenated amorphous silicon (a-Si:H), have been widely integrated into microchips for low-cost, real-time, highly sensitive, miniaturized analysis due to the advantages of optimal optical coupling, good signal-to-noise ratio, and low deposition temperature (below $250^{\circ} \mathrm{C}$ ), which allows for the use of glass, plastic, and polymer substrates [112-114]. Novo et al. [115] developed an indirect competitive ELISA in a PDMS microfluidic chip with integrated a-Si:H photodiode arrays for the chemiluminescence detection of OTA in red wine and beer. OTA-BSA was immobilized into the microchannel inner surface by physical absorption. Compared with a straight-channel configuration, the PDMS microfluidic chip with a two-channel U-shaped configuration can significantly reduce measurement errors, and the LODs of 0.1 and $2 \mu \mathrm{g} / \mathrm{L}$ for beer and red wine, respectively. In addition, Soares [116] developed a regenerable microfluidic immunochip with integrated photosensors for the detection of OTA in red wine. The regeneration protocol was achieved using a glycine solution $(\mathrm{pH}=2)$ to selectively disrupt the interaction between antigen and antibody, and the PDMS chip could be effectively used at least eight times.

Simultaneous detection of multiple mycotoxins by a microfluidic a-Si:H photosensors was also realized. Soares et al. [117] developed a microfluidic multiplexed immunochip utilizing a permanent magnet valve and a single negative pressure source for the simultaneous detection of OTA, AFB1, and DON (three mycotoxins) by the integrated a-Si:H photodetector. Three mycotoxins of $100 \mu \mathrm{g} / \mathrm{L}$ for OTA and DON, and $3 \mu \mathrm{g} / \mathrm{L}$ for AFB1 were detected in less than $20 \mathrm{~min}$. Apart from the abovementioned immunosensors, an aptasensor has also been developed in a microfluidic chip 
with integrated a-Si:H photodiode arrays for mycotoxin detection. Costantini et al. [118] developed an aptamer-based sandwich assay (ALISA) in a multichannel microfluidic chip with an array of a-Si:H photosensors for OTA detection. Aptamer-linked amino was immobilized on a glass substrate modified with succinic anhydride by a condensation reaction. When OTA present in the sample, an aptamer sandwich-like structure will be formed and the generated chemiluminescent signal will be detected by a-Si:H photosensors. The LOD and LOQ of OTA in beer were 0.82 and $2.5 \mu \mathrm{g} / \mathrm{L}$, respectively.

\subsection{Label-Free Detection}

\subsubsection{MS Detection}

The microfluidic chips integrated with LC-MS can reduce matrix interference, sample consumption, and dead volume, improve detection sensitivity, and realize online sample pre-concentration. Jiang et al. [119] fabricated a plastic microfluidic chip and coupled it with ESI-MS for AFB1 detection. The copolyester plastic chip was constructed by a silicon template imprinting technique. The detection sensitivity was increased by 1-2 orders of magnitude compared to the previously reported LC-MS method [120]. Recently, Liu et al. [121] employed a microfluidic chip-based nano LC coupled with a triple quadrupole mass spectrometer (QqQ-MS) system for the quantitative detection of AFs (AFB1, AFB2, AFG1, AFG2, and AFM1) in peanut products. The samples were treated successively by solvent extraction and immunoaffinity SPE for the purification and concentration of target molecules. The LODs were $0.004-0.008 \mu \mathrm{g} / \mathrm{kg}$ and the linear range was $0.048-16 \mu \mathrm{g} / \mathrm{kg}$. The sensitivities of chip-nanoLC-tandem MS were improved about 10 times compared to the conventional HPLC-MS/MS method.

\subsubsection{Surface Plasmon Resonance (SPR) Detection}

SPR has already attracted extensive attention as a label-free method for the detection of mycotoxins due to the short analysis time, simple and rapid cleanup procedures, and reusability [122,123]. SPR is used to monitor the intermolecular interactions on a biosensor chip's surface, such as the interactions of antibodies, aptamers, or molecularly imprinted polymers (MIPs) with the target molecules.

\section{Microchip SPR Sensors Based on Antibodies}

In order to realize the detection of mycotoxins by microchip SPR immunosensors, highly specific single-chain variable antibody fragments (scFvs) of AFB2 were firstly prepared by Edupuganti et al. [124]. Then the microchip SPR sensor based on competitive inhibition immunoassay was developed using scFv-E9 for the detection of AFB2 in a spiked almond sample with an LOD of $0.9 \mu \mathrm{g} / \mathrm{L}$. Then they also generated an anti-ZEA scFv antibody, and used the same approach for the detection of ZEA in sorghum [125]. In addition, Kadota et al. [126] developed a microchip SPR immunosensor using a monoclonal antibody for rapidly measuring the sum of DON and NIV in wheat. The monoclonal antibody cross-reacts with DON and NIV. DON and NIV were purified using an immunoaffinity column, and the recoveries were $91.5 \%-107 \%$. The LODs were $50 \mu \mathrm{g} / \mathrm{kg}$ and $100 \mu \mathrm{g} / \mathrm{kg}$ for DON and NIV, respectively. The results of microchip SPR sensor were correlated with those obtained using LC/MS-MS. T-2 and HT-2 toxins in cereals were also detected using the same method by Meneely et al. [127]. The LODs were determined as $25 \mu \mathrm{g} / \mathrm{kg}$ for baby food and breakfast cereal, and $26 \mu \mathrm{g} / \mathrm{kg}$ for wheat. Then they also used the SPR sensor for the simultaneous determination of the sum of T-2, HT-2, and DON in cereals [128]. LODs of 12,1 , and $29 \mu \mathrm{g} / \mathrm{kg}$ for DON and 31, 47, and $36 \mu \mathrm{g} / \mathrm{kg}$ for HT-2 were found in wheat, breakfast cereal, and maize-based baby food, respectively. Moreover, PTL toxin was also detected by the microchip SPR sensor using the produced polyclonal mono-specific antibodies, which were coated on the sensing interface, and the LOD was $15.41 \mu \mathrm{g} / \mathrm{L}$ [129].

Performing SPR in an imaging format (iSPR) allows for high-throughput detection of mycotoxins. For example, Dorokhin et al. [130] applied a multiplex microassay iSPR immunochip for rapid 
screening of DON and ZEA. DON-OVA and ZEA-OVA conjugates were immobilized on the carboxylated chip surface. The LODs were 84 and $68 \mu \mathrm{g} / \mathrm{kg}$ for DON and 64 and $40 \mu \mathrm{g} / \mathrm{kg}$ for ZEA in maize and wheat samples, respectively. Joshi et al. [131] prepared a portable nanostructured iSPR immunochip for the analysis of DON and OTA in beer with LODs of $17 \mu \mathrm{g} / \mathrm{L}$ for DON and $7 \mu \mathrm{g} / \mathrm{L}$ for OTA. The authors also developed a benchtop SPR (Biacore) with two separate nanostructured iSPR immunochip for the portable and multiplex detection of DON, ZEA, T-2, OTA, FB1, and AFB1 in barley [132]. The LODs were $26 \mu \mathrm{g} / \mathrm{kg}$ for DON, $6 \mu \mathrm{g} / \mathrm{kg}$ for ZEA, $0.6 \mu \mathrm{g} / \mathrm{kg}$ for T-2, $3 \mu \mathrm{g} / \mathrm{kg}$ for OTA, $2 \mu \mathrm{g} / \mathrm{kg}$ for FB1, and $0.6 \mu \mathrm{g} / \mathrm{kg}$ for AFB1. Additionally, they coupled SPR immunochip and ambient ionization MS for the detection of DON in beer (Figure 5) [133]. The coupling of SPR with MS could not only identify the SPR-detected target analytes, but also could distinguish the cross-reacting analytes.

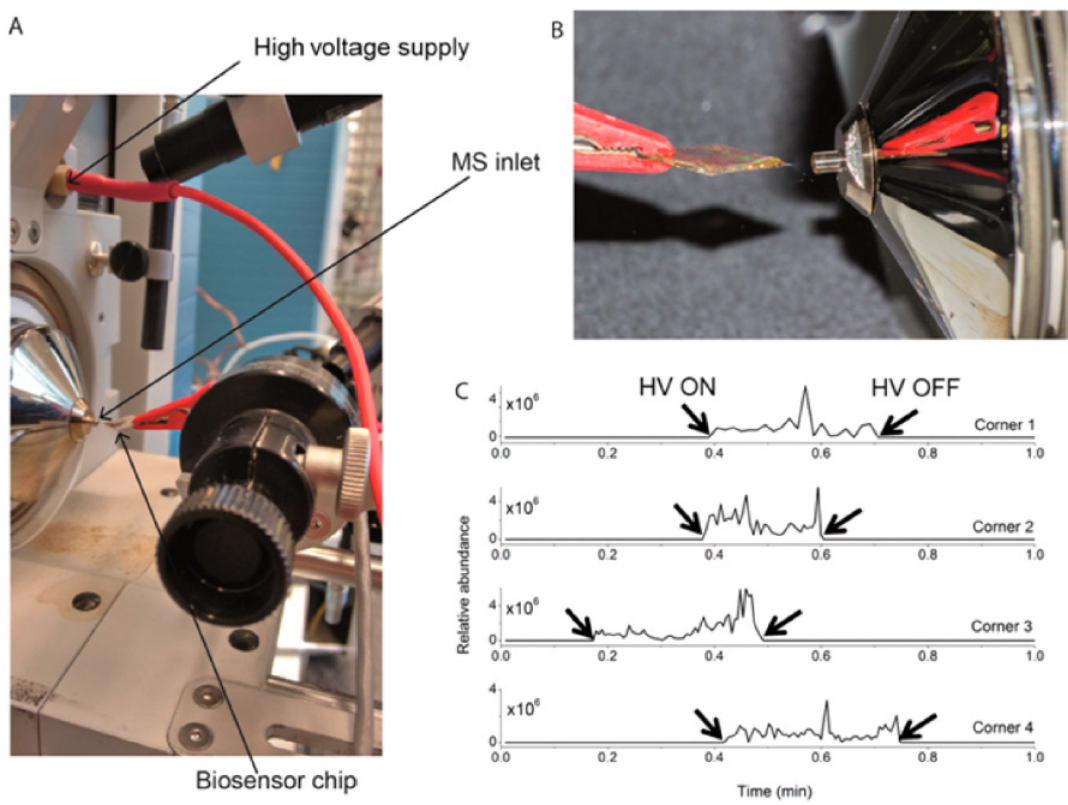

Figure 5. (A) Setup used for Biochip Spray MS using a gold biosensor chip held in front of the MS inlet using an alligator clip and (B) spray obtained after adding $10 \mu \mathrm{L}$ of methanol and applying a voltage of $5 \mathrm{kV}$. (C) Extracted ion chronogram for $m / z 297.1333\left([\mathrm{DON}+\mathrm{H}]^{+}\right.$) recorded in positive ion mode, as obtained from four different corners of a single $1 \mathrm{~cm}^{2}$ square carboxymethylated dextran (CMD) modified gold chip [133]. (Reprinted from reference [133], Copyright (2017), with permission from American Chemical Society).

In order to improve the detection sensitivity of iSPR immunochip, Hu et al. [134] designed a gold-nanoparticle-enhanced iSPR chip for simultaneous detection of AFB1, OTA, and ZEA mycotoxins in spiked peanut samples. The sensing interface was constructed by attaching the antigens of mycotoxins on poly[oligo(ethylene glycol)methacrylate-co-glycidyl methacrylate] (POEGMA-co GMA) brush modified iSPR gold chip. AuNPs-secondary antibody conjugates were combined with the captured monoclonal antibody for further amplification of the iSPR signal. The iSPR chip shows high sensitivity and specificity for AFB1, OTA, and ZEA, with LODs of $0.008,0.03$, and $0.015 \mu \mathrm{g} / \mathrm{L}$, respectively. Moreover, Karczmarczyk et al. $[135,136]$ also utilized the gold-nanoparticle-enhanced SPR immunochip for the detection of OTA in red wine and AFM1 in milk; the LODs were $0.068 \mu \mathrm{g} / \mathrm{L}$ for OTA and $0.018 \mu \mathrm{g} / \mathrm{L}$ for AFM1.

However, the immobilization of antibodies on the sensing interface by physical adsorption or covalent binding can lead to instability and loss of binding capacity in antibodies. An effective method was constructed by Park et al. [137] for immobilizing antibodies on the sensing surface. They firstly produced a gold binding protein (GBP)-protein $\mathrm{G}$ (ProG) bifunctional crosslinker by genetic engineering, and then used the GBP-ProG crosslinker for the immobilization of antibodies on chip gold substrates 
without any chemical treatment. The fabricated SPR chips based on the GBP-ProG crosslinker were used for the detection of AFB1 in both buffer and corn extracts with the LOD of $1000 \mu \mathrm{g} / \mathrm{L}$.

\section{Microchip SPR Biosensors Based on Aptamers}

In recent years, microchip SPR biosensors based on aptamers also have been applied to the detection of mycotoxins. Zhu et al. [138] established a SPR biosensor chip using anti-OTA aptamers for quantitative detection of OTA in wine and peanut oil. The streptavidin was immobilized onto the chip surface with dextran matrix using an amine coupling method; the biotin-aptamer was captured by the interaction of streptavidin and biotin. The SPR biosensor gives high sensitivity with an LOD of $0.005 \mu \mathrm{g} / \mathrm{L}$ and a linear range of $0.094-10 \mu \mathrm{g} / \mathrm{L}$. AFB1 in red wine and beer was also detected using the same approach, with an LOD of $124.91 \mu \mathrm{g} / \mathrm{L}$, by Sun et al. [139].

A localized SPR (LSPR) biosensor system formed by the immobilization of colloidal metal nanoparticles on surfaces has several advantages, such as device miniaturization, regeneration and reuse, and multiplex detection. Park et al. [140] prepared a LSPR aptasensor chip for the detection of OTA in ground corn samples. OTA aptamer immobilized on the surfaces of gold nanorods (GNRs) will self-assemble into a G-quadruplex structure when it interacts with OTA, and the LOD was below $403 \mu \mathrm{g} / \mathrm{L}$. This LSPR biosensor chip was first developed for the detection of small molecules. Additionally, Bianco et al. [141] developed an aptamer-based SPR-polarization biosensor chip for the detection of OTA, with an LOD of $0.005 \mu \mathrm{g} / \mathrm{L}$. The phase-interrogation SPR biosensor chip was found to be a highly sensitive detection technique with potential use as portable device.

\section{Microchip SPR Biosensors Based on MIP}

Compared to the antibody and aptamer, MIP is a synthetic recognition element that can remain stable in harsh conditions, such as high temperature and pressure, extreme $\mathrm{pH}$, and even organic solvents. MIP technique is an effective method in terms of specific recognition. Hence, microchip SPR biosensors based on MIP have many advantages including high specificity, sensitivity, and selectivity. Choi et al. [142] fabricated a SPR biosensor chip based on MIP for the detection of DON. An MIP film of $5 \mathrm{~nm}$ thickness was prepared on a bare Au chip using pyrrole by electropolymerization when DON was a template. The SPR biosensor chip exhibited a linear response in the range of $0.1-100 \mu \mathrm{g} / \mathrm{L}$ for a DON standard solution, and the LOD was about at $>1 \mu \mathrm{g} / \mathrm{L}$. Moreover, the authors also detected ZEA in corn using this method, with an LOD of $0.3 \mu \mathrm{g} / \mathrm{kg}$ [143]. Moreover, Atar et al. [144] prepared CIT-imprinted poly(2-hydroxyethyl methacrylate-methacryloylamidoglutamic acid) (p(HEMA-MAGA)) film on the gold surface of SPR chip for the detection of CIT in red yeast rice. The linearity range was 0.005-1.0 $\mu \mathrm{g} / \mathrm{L}$ and the LOD was $0.0017 \mu \mathrm{g} / \mathrm{L}$. In addition, Gupta et al. [145] prepared nanopatterned $\pi$-conjugated MIP on a SPR chip for supersensitive detection of T-2 by in situ electropolymerization of T-2 with 3-aminophenylboronicacid (3-APBA). The developed method showed a linear response from $0.98 \times 10^{-3}$ to $0.016 \mu \mathrm{g} / \mathrm{L}$ for T-2, and the LOD was $0.47 \times 10^{-4} \mu \mathrm{g} / \mathrm{L}$. In conclusion, the microchip SPR biosensor chip based on MIP is a sensitive, rapid, cheap, robust, and easy method for the detection of mycotoxins.

\subsubsection{Surface-Enhanced Raman Spectroscopy (SERS) Detection}

SERS is an ultrasensitive, nondestructive, and noninvasive spectroscopic technique for the detection of molecules on or near the surface of plasmonic nanostructures [146]. As another ultrasensitive label-free analytical tool, SERS has also been successfully applied in the detection of mycotoxins. For instance, Galarreta et al. [147] prepared a metallic nanostructure 2D SERS platform on a glass coverslip surface by electron beam lithography, and embedded it into a PDMS microfluidic channel for the detection of OTA. An HS-aptamer of OTA was immobilized onto the metallic nanostructure. When OTA was present in the sample, the Raman spectrum of the OTA-aptamer complex was subsequently acquired. Additionally, Li et al. [148] constructed a SERS aptasensor chip based on exonuclease-assisted recycling amplification for the ultrasensitive determination of 
AFB1 in spiked peanuts. When AFB1 is present in the sample, AFB1 aptamers will be released from the hybridization duplex strands of AFB1 aptamers and their partial complementary strands, and immediately hybridized with hairpin DNA on the Au film of chip surface. Then the hairpin DNA was hydrolyzed by exonuclease III at a restriction site, leaving short single-stranded DNA to capture Raman tags via hybridization on Au film and releasing complementary DNA for recycling. Hence, a large number of Raman probes were anchored on the Au film of the chip. High sensitivity and good selectivity for the detection of AFB1 were obtained. The linear range and LOD were determined to be $1 \times 10^{-6}-1 \mu \mathrm{g} / \mathrm{L}$ and $0.4 \times 10^{-6} \mu \mathrm{g} / \mathrm{L}$, respectively. These aptamer-SERS sensing chips provide an important application for more rapid and portable determination of mycotoxins.

\subsubsection{Optical Waveguide Lightmode Spectroscopy (OWLS) Detection}

OWLS, another highly sensitive, rapid label-free detection method, has also been applied successfully to detect the interaction between antigen and antibody. OWLS uses evanescent field for the in situ study of surface processes at a molecular level. So far, there have been few reports about the development of an OWLS sensor chip for the detection of mycotoxins. Majer-Baranyi et al. [149] applied direct and indirect immunoassays using DON polyclonal antibodies in OWLS sensor chips for the detection of DON. The direct OWLS immunochip showed an unstable sensor response and a low sensitivity above $1 \mu \mathrm{g} / \mathrm{L}$ for DON in a real sample, not being sufficient for DON determination. In contrast, the competitive OWLS immunochip provided reproducible quantitative detection in the concentration range of $5-5 \times 10^{4} \mu \mathrm{g} / \mathrm{kg}$ for DON spiked in wheat flour. Recently, they also detected AFB1 in spice paprika samples using the same method, with an LOD of $0.35 \mu \mathrm{g} / \mathrm{kg}$ [150]. In addition, Adányi et al. [151] also developed an OWLS immunochip for determining AFB1 and OTA in barley and wheat flour samples using competitive and direct immunoassays. All of the results showed that OWLS immunochips have the potential for rapid, highly sensitive detection of mycotoxins in foods.

\subsubsection{Broad-Band Mach-Zehnder Interferometry (BB-MZI) Detection}

SPR, SERS, and OWLS sensors have excellent sensitivity, but they need external optical components, especially laser sources for excitation. Hence, these label-free detection methods need expensive and large-scale instruments that make them appropriate to be used only in the lab. In order to move detection methods from the lab to the field, Pagkali et al. [152] developed a novel, regenerated, reused label-free immunochip based on monolithically integrated arrays of Broad-Band Mach-Zehnder Interferometry (BB-MZI) along with their respective light-emitting diodes (LEDs) for the detection of OTA in beer. An OTA-OVA conjugate was immobilized on the sensing arm area of BB-MZI. The LOD of OTA in beer was $2.0 \mu \mathrm{g} / \mathrm{L}$, and the dynamic detecting range was $4-100 \mu \mathrm{g} / \mathrm{L}$. The miniaturized biosensor chip is suitable for the development of a portable instrument for point-of-need determination.

\subsubsection{Giant Magnetoresistive Detection}

Here, Mak et al. [153] integrated the sandwich immunoassay into a new multiplex magnetic nanotag-based biochip detection platform for the simultaneous detection of multiple mycotoxins including AFB1, ZEA, and HT-2. The sensitivity can be up to sub-picomolar concentration level, and the LOD was $0.05 \mu \mathrm{g} / \mathrm{L}$. Compared to the fluorescent labels, magnetic nanotags (MNTs) can be detected with low-cost giant magnetoresistive (GMR) sensors such as spin-valve. The GMR biosensor chip system has the capacity for low-cost, real-time, and rapid detection of multiplex mycotoxins.

\section{Conclusions}

In conclusion, microchips, including microfluidic chips and microarray chips, can be employed in mycotoxin determination in foods by optical detection, electrochemical detection, photo-electrochemical detection, or a label-free detection method. A microchip is an innovative method that could convert conventional methods into more efficient micro-scale devices due to its unique properties of automation, integration, portability, high throughput, low sample consumption, 
and rapid sensing time. However, most microchips applied to mycotoxin determination are used only in the lab due to the large-scale detecting instruments. Hence, one of the major challenges of microchips for the detection of mycotoxins is to minimize the detecting instruments in order to move detection methods from the lab to the field. Additionally, the complexity of sample matrices, the diversity of mycotoxins, and the electrostatic force of microchip channels are also major challenges in the use of microchips for the detection of mycotoxins. Hence, sample pretreatment is essential before biochip analysis for high-sensitivity and -specificity detection. So far, most of the sample pretreatments were realized off-chip. So, scientists have to exert more effort and spend more time on the realization of on-chip sample pretreatments. Furthermore, in view of the diversity of mycotoxins, multiplex detection remains a goal for the future. Meanwhile, in order to avoid the sample adsorption that was caused by the electrostatic force of the microchips, new chip materials without adsorption property, or physical adsorption coating and chemical bonding coating, need to be developed. Efforts should focus on the integration of other separation methods and detection techniques into the biochip systems. Paper-based biochips, regenerable biochips, and multi-channel biochips will be popular in the determination of mycotoxins. The commercial application of microchip devices is the ultimate goal for the detection of mycotoxins in foods.

Table 3. Microchips integrated various kinds of detection methods for detecting mycotoxins.

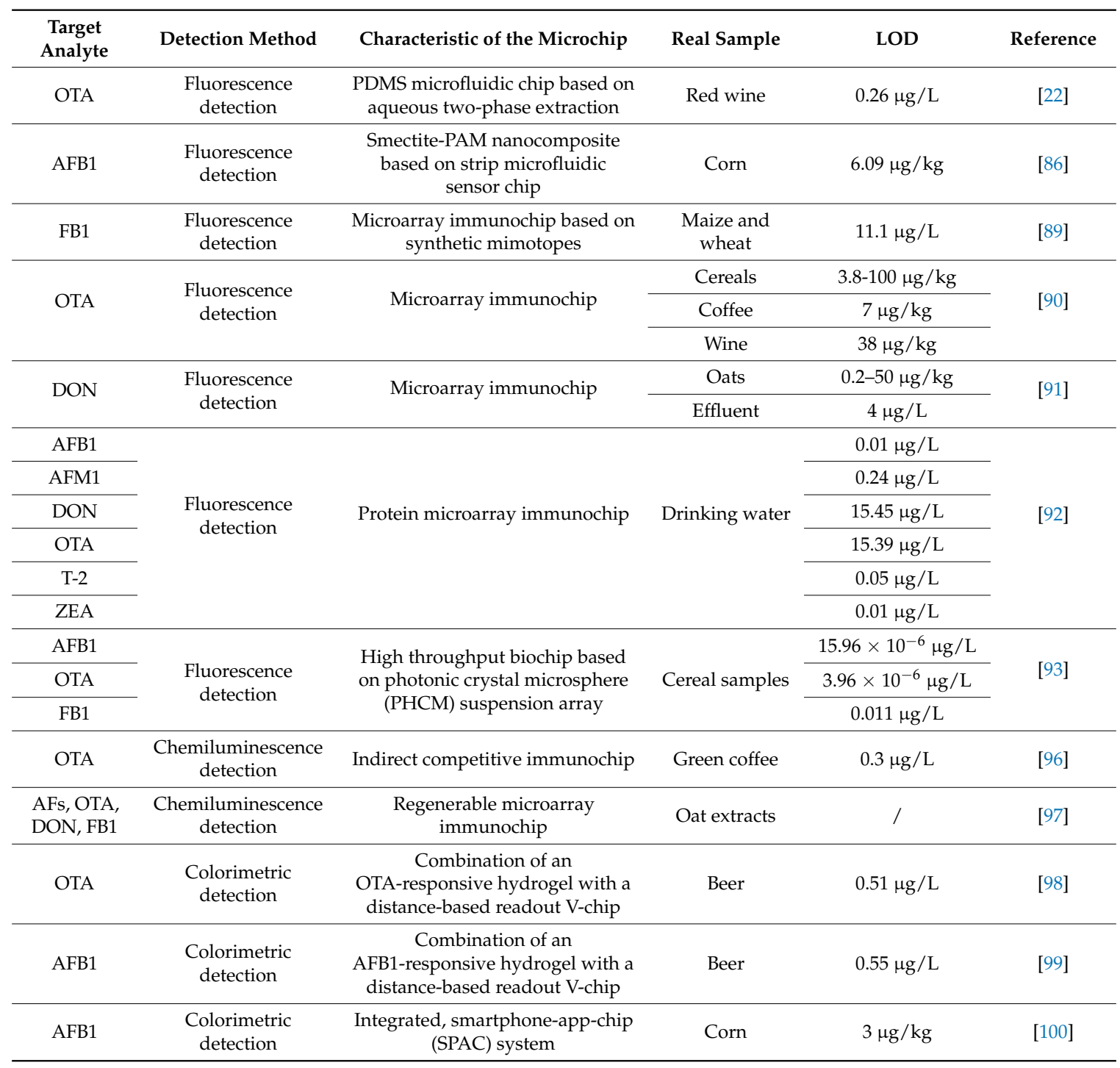


Table 3. Cont.

\begin{tabular}{|c|c|c|c|c|c|}
\hline $\begin{array}{c}\text { Target } \\
\text { Analyte }\end{array}$ & Detection Method & Characteristic of the Microchip & Real Sample & LOD & Reference \\
\hline AFB1 & $\begin{array}{l}\text { Electrochemical } \\
\text { detection }\end{array}$ & $\begin{array}{l}\text { 96-well screen-printed microarray } \\
\text { immunochip }\end{array}$ & Corn & $0.03 \mu \mathrm{g} / \mathrm{L}$ & [103] \\
\hline AFM1 & $\begin{array}{l}\text { Electrochemical } \\
\text { detection }\end{array}$ & $\begin{array}{l}\text { Gold microelectrode array } \\
\text { immunochip }\end{array}$ & Milk & $0.008 \mu \mathrm{g} / \mathrm{L}$ & [104] \\
\hline CIT & $\begin{array}{l}\text { Electrochemical } \\
\text { detection }\end{array}$ & $\begin{array}{l}\text { Microfluidic electrochemical } \\
\text { immunochip }\end{array}$ & Rice & $0.1 \mu \mathrm{g} / \mathrm{L}$ & [105] \\
\hline DON & $\begin{array}{l}\text { Electrochemical } \\
\text { detection }\end{array}$ & $\begin{array}{l}\text { Microfluidic chip coupled with } \\
\text { gold microelectrode arrays }\end{array}$ & Wheat & $6.25 \mu \mathrm{g} / \mathrm{L}$ & [106] \\
\hline $\mathrm{AF}$ & $\begin{array}{l}\text { Electrochemical } \\
\text { detection }\end{array}$ & $\begin{array}{l}\text { Microfluidic chip coupled with } \\
\text { gold microelectrode arrays }\end{array}$ & Foods & $0.08-0.65 \mu \mathrm{g} / \mathrm{kg}$ & [107] \\
\hline ZEA & $\begin{array}{l}\text { Electrochemical } \\
\text { detection }\end{array}$ & $\begin{array}{l}\text { Microfluidic chips coupled with } \\
\text { magnetic bead-based } \\
\text { immunoassay }\end{array}$ & Baby foods & $1 \mu \mathrm{g} / \mathrm{kg}$ & [108] \\
\hline ZEA & $\begin{array}{l}\text { Electrochemical } \\
\text { detection }\end{array}$ & $\begin{array}{l}\text { Microfluidic chips coupled with } \\
\text { magnetic bead-based } \\
\text { immunoassay }\end{array}$ & Infant foods & $0.4 \mu \mathrm{g} / \mathrm{L}$ & [109] \\
\hline ZEA & $\begin{array}{l}\text { Electrochemical } \\
\text { detection }\end{array}$ & $\begin{array}{l}\text { Microfluidic chips coupled with } \\
\text { magnetic bead-based ELISA }\end{array}$ & Feedstuffs & $0.41 \mu \mathrm{g} / \mathrm{L}$ & [110] \\
\hline OTA & $\begin{array}{l}\text { Electrochemical } \\
\text { detection }\end{array}$ & $\begin{array}{l}\text { Microfluidic chips coupled with } \\
\text { magnetic bead-based ELISA }\end{array}$ & Apples & $50 \mu \mathrm{g} / \mathrm{kg}$ & [111] \\
\hline \multirow[t]{2}{*}{ OTA } & \multirow{2}{*}{$\begin{array}{l}\text { Photo-electrochemical } \\
\text { detection }\end{array}$} & \multirow{2}{*}{$\begin{array}{l}\text { Chemiluminescence-based ELISA } \\
\text { in microfluidic chip with } \\
\text { integrated photodiodes }\end{array}$} & Beer & $0.1 \mu \mathrm{g} / \mathrm{L}$ & \multirow[t]{2}{*}{ [115] } \\
\hline & & & Red wine & $2 \mu \mathrm{g} / \mathrm{L}$ & \\
\hline OTA & $\begin{array}{l}\text { Photo-electrochemical } \\
\text { detection }\end{array}$ & $\begin{array}{c}\text { Regenerable } \\
\text { chemiluminescence-based } \\
\text { immunoassay in microfluidic chip } \\
\text { with integrated photodiodes }\end{array}$ & Red wine & $<2 \mu \mathrm{g} / \mathrm{L}$ & [116] \\
\hline $\begin{array}{l}\text { OTA, AFB1 } \\
\text { and DON }\end{array}$ & $\begin{array}{l}\text { Photo-electrochemical } \\
\text { detection }\end{array}$ & $\begin{array}{c}\text { Microfluidic multiplexed } \\
\text { biosensor chip with a permanent } \\
\text { magnet valves }\end{array}$ & / & / & [117] \\
\hline OTA & $\begin{array}{l}\text { Photo-electrochemical } \\
\text { detection }\end{array}$ & $\begin{array}{l}\text { Aptamer-based sandwich assay in } \\
\text { a multichannel microfluidic chip }\end{array}$ & Beer & $0.82 \mu \mathrm{g} / \mathrm{L}$ & [118] \\
\hline AFB1 & MS & $\begin{array}{l}\text { Plastic microfluidic chip coupled } \\
\text { with ESI-MS }\end{array}$ & / & / & [119] \\
\hline AFs & MS & $\begin{array}{l}\text { Microfluidic chip-based nano LC } \\
\text { coupled with QqQ-MS }\end{array}$ & Peanut & $0.004-0.008 \mu \mathrm{g} / \mathrm{kg}$ & [121] \\
\hline AFB2 & SPR & $\begin{array}{l}\text { Microchip SPR immunochip using } \\
\text { anti-AFB2 scFv antibody }\end{array}$ & Almond & $0.9 \mu \mathrm{g} / \mathrm{L}$ & [124] \\
\hline ZEA & SPR & $\begin{array}{l}\text { Microchip SPR immunochip using } \\
\text { anti-ZEA scFv antibody }\end{array}$ & Sorghum & $7.8 \mu \mathrm{g} / \mathrm{L}$ & [125] \\
\hline NIV & \multirow{2}{*}{ SPR } & \multirow{2}{*}{$\begin{array}{l}\text { Microchip SPR immunochip using } \\
\text { monoclonal antibody }\end{array}$} & \multirow{2}{*}{ Wheat } & $200 \mu \mathrm{g} / \mathrm{kg}$ & \multirow{2}{*}{ [126] } \\
\hline DON & & & & $100 \mu \mathrm{g} / \mathrm{kg}$ & \\
\hline \multirow[t]{2}{*}{$\begin{array}{l}\text { T-2 and } \\
\text { HT-2 }\end{array}$} & \multirow[t]{2}{*}{ SPR } & \multirow[t]{2}{*}{$\begin{array}{l}\text { Microchip SPR immunochip using } \\
\text { monoclonal antibody }\end{array}$} & $\begin{array}{l}\text { Baby food and } \\
\text { breakfast cereal }\end{array}$ & $25 \mu \mathrm{g} / \mathrm{kg}$ & \multirow[t]{2}{*}{ [127] } \\
\hline & & & Wheat & $26 \mu \mathrm{g} / \mathrm{kg}$ & \\
\hline \multirow{3}{*}{$\begin{array}{l}\text { T-2 } \\
\text { HT-2 }\end{array}$} & \multirow{6}{*}{ SPR } & \multirow{6}{*}{$\begin{array}{l}\text { Microchip SPR immunochip using } \\
\text { monoclonal antibody }\end{array}$} & Wheat & $31 \mu \mathrm{g} / \mathrm{kg}$ & \multirow{6}{*}{ [128] } \\
\hline & & & Breakfast cereal & $47 \mu \mathrm{g} / \mathrm{kg}$ & \\
\hline & & & $\begin{array}{l}\text { Maize-based } \\
\text { baby food }\end{array}$ & $36 \mu \mathrm{g} / \mathrm{kg}$ & \\
\hline \multirow{3}{*}{ DON } & & & Wheat & $12 \mu \mathrm{g} / \mathrm{kg}$ & \\
\hline & & & Breakfast cereal & $1 \mu \mathrm{g} / \mathrm{kg}$ & \\
\hline & & & $\begin{array}{l}\text { Maize-based } \\
\text { baby food }\end{array}$ & $29 \mu \mathrm{g} / \mathrm{kg}$ & \\
\hline PTL & SPR & $\begin{array}{l}\text { Microchip SPR immunochip using } \\
\text { polyclonal mono-specific } \\
\text { antibodies }\end{array}$ & / & $15.41 \mu \mathrm{g} / \mathrm{L}$ & [129] \\
\hline
\end{tabular}


Table 3. Cont.

\begin{tabular}{|c|c|c|c|c|c|}
\hline $\begin{array}{l}\text { Target } \\
\text { Analyte }\end{array}$ & Detection Method & Characteristic of the Microchip & Real Sample & LOD & Reference \\
\hline \multirow{2}{*}{ DON } & \multirow{4}{*}{ iSPR } & \multirow{4}{*}{$\begin{array}{l}\text { Microchip multiplex microassay } \\
\text { iSPR immunochip }\end{array}$} & Maize & $84 \mu \mathrm{g} / \mathrm{kg}$ & \multirow{4}{*}{ [130] } \\
\hline & & & Wheat & $68 \mu \mathrm{g} / \mathrm{kg}$ & \\
\hline \multirow{2}{*}{ ZEA } & & & Maize & $64 \mu \mathrm{g} / \mathrm{kg}$ & \\
\hline & & & Wheat & $40 \mu \mathrm{g} / \mathrm{kg}$ & \\
\hline DON & \multirow{2}{*}{ iSPR } & \multirow{2}{*}{$\begin{array}{l}\text { Microchip nanostructured iSPR } \\
\text { immunochip }\end{array}$} & \multirow{2}{*}{ Beer } & $17 \mu \mathrm{g} / \mathrm{L}$ & \multirow{2}{*}{ [131] } \\
\hline OTA & & & & $7 \mu \mathrm{g} / \mathrm{L}$ & \\
\hline DON & \multirow{6}{*}{ iSPR } & \multirow{6}{*}{$\begin{array}{l}\text { Microchip benchtop SPR (Biacore) } \\
\text { with two separates } \\
\text { nanostructured iSPR immunochip }\end{array}$} & \multirow{6}{*}{ Barley } & $26 \mu \mathrm{g} / \mathrm{kg}$ & \multirow{6}{*}{ [132] } \\
\hline ZEA & & & & $6 \mu \mathrm{g} / \mathrm{kg}$ & \\
\hline $\mathrm{T}-2$ & & & & $0.6 \mu \mathrm{g} / \mathrm{kg}$ & \\
\hline OTA & & & & $3 \mu \mathrm{g} / \mathrm{kg}$ & \\
\hline FB1 & & & & $2 \mu \mathrm{g} / \mathrm{kg}$ & \\
\hline AFB1 & & & & $0.6 \mu \mathrm{g} / \mathrm{kg}$ & \\
\hline DON & SPR-MS & $\begin{array}{l}\text { Coupled SPR immunochip and } \\
\text { ambient ionization MS }\end{array}$ & Beer & / & [133] \\
\hline AFB1 & \multirow{3}{*}{ iSPR } & \multirow{3}{*}{$\begin{array}{l}\text { AuNP-enhanced iSPR } \\
\text { immunochip }\end{array}$} & \multirow{3}{*}{ Spiked peanut } & $0.008 \mu \mathrm{g} / \mathrm{L}$ & \multirow{3}{*}{ [134] } \\
\hline OTA & & & & $0.03 \mu \mathrm{g} / \mathrm{L}$ & \\
\hline AEN & & & & $0.015 \mu \mathrm{g} / \mathrm{L}$ & \\
\hline OTA & SPR & $\begin{array}{l}\text { AuNP-enhanced SPR } \\
\text { immunochip }\end{array}$ & Red wine & $0.068 \mu \mathrm{g} / \mathrm{L}$ & [135] \\
\hline AFM1 & SPR & $\begin{array}{l}\text { AuNP-enhanced SPR } \\
\text { immunochip }\end{array}$ & Milk & $0.018 \mu \mathrm{g} / \mathrm{L}$ & [136] \\
\hline AFB1 & SPR & $\begin{array}{l}\text { SPR immunochip based on } \\
\text { GBP-ProG crosslinker }\end{array}$ & $\begin{array}{l}\text { Buffer and corn } \\
\text { extracts }\end{array}$ & $1000 \mu \mathrm{g} / \mathrm{L}$ & [137] \\
\hline OTA & SPR & SPR microchip based on aptamer & $\begin{array}{l}\text { Wine and } \\
\text { peanut oil }\end{array}$ & $0.005 \mu \mathrm{g} / \mathrm{L}$ & [138] \\
\hline AFB1 & SPR & SPR microchip based on aptamer & Red wine & $124.91 \mu \mathrm{g} / \mathrm{L}$ & [139] \\
\hline OTA & SPR & $\begin{array}{l}\text { Localized SPR microchip based on } \\
\text { aptamer }\end{array}$ & $\begin{array}{l}\text { Ground corn } \\
\text { samples }\end{array}$ & $403 \mu \mathrm{g} / \mathrm{L}$ & [140] \\
\hline OTA & SRP & $\begin{array}{l}\text { SPR-polarization microchip based } \\
\text { on aptamer }\end{array}$ & / & $0.005 \mu \mathrm{g} / \mathrm{L}$ & [141] \\
\hline DON & SPR & SPR microchip based on MIP & $\begin{array}{l}\text { DON standard } \\
\text { solution }\end{array}$ & $>1 \mu \mathrm{g} / \mathrm{L}$ & [142] \\
\hline ZEA & SPR & SPR microchip based on MIP & Corn & $0.3 \mu \mathrm{g} / \mathrm{kg}$ & [143] \\
\hline CIT & SPR & SPR biosensor chip based on MIP & Red yeast rice & $0.0017 \mu \mathrm{g} / \mathrm{L}$ & [144] \\
\hline $\mathrm{T}-2$ & SPR & $\begin{array}{c}\text { SPR microchip based on } \\
\text { nanopatterned } \pi \text {-conjugated MIP }\end{array}$ & / & $0.47 \times 10^{-4} \mu \mathrm{g} / \mathrm{L}$ & [145] \\
\hline OTA & SERS & $\begin{array}{l}\text { Microfluidic chip embedded 2D } \\
\text { SERS platform }\end{array}$ & / & / & [147] \\
\hline AFB1 & SERS & $\begin{array}{l}\text { SERS aptasensor chip based on } \\
\text { exonuclease-assisted } \\
\text { recycling amplification }\end{array}$ & Spiked peanuts & $0.4 \times 10^{-6} \mu \mathrm{g} / \mathrm{L}$ & [148] \\
\hline DON & OWLS & Immunochip based on OWLS & Wheat flour & / & [149] \\
\hline AFB1 & OWLS & Immunochip based on OWLS & $\begin{array}{l}\text { Spice paprika } \\
\text { samples }\end{array}$ & $0.35 \mu \mathrm{g} / \mathrm{kg}$ & [150] \\
\hline AFB1, OTA & OWLS & Immunochip based on OWLS & $\begin{array}{l}\text { Barley and } \\
\text { wheat flour } \\
\text { samples }\end{array}$ & / & [151] \\
\hline OTA & BB-MZI & $\begin{array}{l}\text { Si immunochip based on } \\
\text { monolithically integrated BB-MZI }\end{array}$ & Beer & $2.0 \mu \mathrm{g} / \mathrm{L}$ & [152] \\
\hline $\begin{array}{l}\text { AFB1, ZEA, } \\
\text { HT-2 }\end{array}$ & GMR & $\begin{array}{l}\text { Multiplex magnetic } \\
\text { nanotag-based biochip }\end{array}$ & / & $0.05 \mu \mathrm{g} / \mathrm{L}$ & [153] \\
\hline
\end{tabular}


Acknowledgments: This work was supported by the project of Beijing Excellent Talents (2016000020060G127), National High Technology Research and Development Program of China (Grant No. 2013AA102302) and the open projects of Beijing Research Center for Agricultural Standards and Testing (kfkt201709).

Author Contributions: Yan Man and Ligang Pan conceived and designed the experiments; Gang Liang and An $\mathrm{Li}$ analyzed the data; Yan Man wrote the paper.

Conflicts of Interest: The authors declare no conflicts of interest.

\section{References}

1. Xu, L.; Zhang, Z.; Zhang, Q.; Li, P. Mycotoxin determination in foods using advanced sensors based on antibodies or aptamers. Toxins 2016, 8, 239. [CrossRef] [PubMed]

2. Gallo, A.; Giuberti, G.; Frisvad, J.; Bertuzzi, T.; Nielsen, K. Review on mycotoxin issues in ruminants: Occurrence in forages, effects of mycotoxin ingestion on health status and animal performance and practical strategies to counteract their negative effects. Toxins 2015, 7, 3057-3111. [CrossRef] [PubMed]

3. Kong, D.; Liu, L.; Song, S.; Suryoprabowo, S.; Li, A.; Kuang, H.; Wang, L.; Xu, C. A gold nanoparticle-based semi-quantitative and quantitative ultrasensitive paper sensor for the detection of twenty mycotoxins. Nanoscale 2016, 8, 5245-5253. [CrossRef] [PubMed]

4. Berthiller, F.; Crews, C.; Dall'Asta, C.; Saeger, S.D.; Haesaert, G.; Karlovsky, P.; Oswald, I.P.; Seefelder, W.; Speijers, G.; Stroka, J. Masked mycotoxins: A review. Mol. Nutr. Food Res. 2013, 57, 165-186. [CrossRef] [PubMed]

5. Van Egmond, H.P.; Schothorst, R.C.; Jonker, M.A. Regulations relating to mycotoxins in food. Anal. Bioanal. Chem. 2007, 389, 147-157. [CrossRef] [PubMed]

6. Campagnollo, F.B.; Ganev, K.C.; Khaneghah, A.M.; Portela, J.B.; Cruz, A.G.; Granato, D.; Corassin, C.H.; Oliveira, C.A.F.; Sant'Ana, A.S. The occurrence and effect of unit operations for dairy products processing on the fate of aflatoxin M1: A review. Food Control 2016, 68, 310-329. [CrossRef]

7. Anfossi, L.; Giovannoli, C.; Baggiani, C. Mycotoxin detection. Curr. Opin. Biotechnol. 2016, 37, $120-126$. [CrossRef] [PubMed]

8. Piacentini, K.C.; Rocha, L.O.; Fontes, L.C.; Carnielli, L.; Reis, T.A.; Corrêa, B. Mycotoxin analysis of industrial beers from Brazil: The influence of fumonisin B1 and deoxynivalenol in beer quality. Food Chem. 2017, 218, 64-69. [CrossRef] [PubMed]

9. Bensassi, F.; Zaied, C.; Abid, S.; Hajlaoui, M.R.; Bacha, H. Occurrence of deoxynivalenol in durum wheat in Tunisia. Food Control 2010, 21, 281-285. [CrossRef]

10. Soleimany, F.; Jinap, S.; Rahmani, A.; Khatib, A. Simultaneous detection of 12 mycotoxins in cereals using RP-HPLC-PDA-FLD with PHRED and a post-column derivatization system. Food Addit. Contam. A 2011, 28, 494-501. [CrossRef] [PubMed]

11. Kong, W.J.; Shen, H.H.; Zhang, X.F.; Yang, X.L.; Qiu, F.; Ou-yang, Z.; Yang, M.H. Analysis of zearalenone and $\alpha$-zearalenol in 100 foods and medicinal plants determined by HPLC-FLD and positive confirmation by LC-MS-MS. J. Sci. Food Agric. 2013, 93, 1584-1590. [CrossRef] [PubMed]

12. Meca, G.; Zinedine, A.; Blesa, J.; Font, G.; Mañes, J. Further data on the presence of Fusarium emerging mycotoxins enniatins, fusaproliferin and beauvericin in cereals available on the Spanish markets. Food Chem. Toxicol. 2010, 48, 1412-1416. [CrossRef] [PubMed]

13. Mornar, A.; Sertić, M.; Nigović, B. Development of a rapid LC/DAD/FLD/MSn method for the simultaneous determination of monacolins and citrinin in red fermented rice products. J. Agric. Food Chem. 2013, 61, 1072-1080. [CrossRef] [PubMed]

14. Walravens, J.; Mikula, H.; Rychlik, M.; Asam, S.; Devos, T.; Njumbe Ediage, E.; Diana Di Mavungu, J.; Jacxsens, L.; Van Landschoot, A.; Vanhaecke, L.; et al. Validated UPLC-MS/MS methods to quantitate free and conjugated alternaria toxins in commercially available tomato products and fruit and vegetable juices in belgium. J. Agric. Food Chem. 2016, 64, 5101-5109. [CrossRef] [PubMed]

15. Varga, E.; Glauner, T.; Berthiller, F.; Krska, R.; Schuhmacher, R.; Sulyok, M. Development and validation of a (semi-) quantitative UHPLC-MS/MS method for the determination of 191 mycotoxins and other fungal metabolites in almonds, hazelnuts, peanuts and pistachios. Anal. Bioanal. Chem. 2013, 405, 5087-5104. [CrossRef] [PubMed] 
16. Huang, L.C.; Zheng, N.; Zheng, B.Q.; Wen, F.; Cheng, J.B.; Han, R.W.; Xu, X.M.; Li, S.L.; Wang, J.Q. Simultaneous determination of aflatoxin M1, ochratoxin A, zearalenone and $\alpha$-zearalenol in milk by UHPLC-MS/MS. Food Chem. 2014, 146, 242-249. [CrossRef] [PubMed]

17. Horiuchi, M.; Akimoto, N.; Ohnishi, K.; Yamashita, M.; Maoka, T. Rapid and simultaneous determination of tetra cyclic peptide phytotoxins, tentoxin, isotentoxin and dihydrotentoxin, from Alternaria porri by LC/MS. Chromatogr.-Tokyo-Soc. Chromatogr. Sci. 2003, 24, 109-116.

18. Prelle, A.; Spadaro, D.; Garibaldi, A.; Gullino, M.L. A new method for detection of five alternaria toxins in food matrices based on LC-APCI-MS. Food Chem. 2013, 140, 161-167. [CrossRef] [PubMed]

19. Di Mavungu, D.; De Saeger, S. Masked mycotoxins in food and feed: Challenges and analytical approaches. In Determining Mycotoxins and Mycotoxigenic Fungi in Food and Feed; Mavungu, J.D.D., Saeger, S.D., Eds.; Woodhead: Cambridge, UK, 2011; Volume 203, pp. 385-400.

20. Dzuman, Z.; Vaclavikova, M.; Polisenska, I.; Veprikova, Z.; Fenclova, M.; Zachariasova, M.; Hajslova, J. Enzyme-linked immunosorbent assay in analysis of deoxynivalenol: Investigation of the impact of sample matrix on results accuracy. Anal. Bioanal. Chem. 2014, 406, 505-514. [CrossRef] [PubMed]

21. Soares, R.R.G.; Novo, P.; Azevedo, A.M.; Fernandes, P.; Chu, V.; Conde, J.P.; Aires-Barros, M.R. Aqueous two-phase systems for enhancing immunoassay sensitivity: Simultaneous concentration of mycotoxins and neutralization of matrix interference. J. Chromatogr. A 2014, 1361, 67-76. [CrossRef] [PubMed]

22. Soares, R.R.; Novo, P.; Azevedo, A.M.; Fernandes, P.; Aires-Barros, M.R.; Chu, V.; Conde, J.P. On-chip sample preparation and analyte quantification using a microfluidic aqueous two-phase extraction coupled with an immunoassay. Lab Chip 2014, 14, 4284-4294. [CrossRef] [PubMed]

23. Zhang, Z.; Yu, L.; Xu, L.; Hu, X.; Li, P.; Zhang, Q.; Ding, X.; Feng, X. Biotoxin sensing in food and environment via microchip. Electrophoresis 2014, 35, 1547-1559. [CrossRef] [PubMed]

24. Mark, D.; Haeberle, S.; Roth, G.; von Stetten, F.; Zengerle, R. Microfluidic lab-on-a-chip platforms: Requirements, characteristics and applications. Chem. Soc. Rev. 2010, 39, 1153-1182. [CrossRef] [PubMed]

25. Williams, J.H.; Phillips, T.D.; Jolly, P.E.; Stiles, J.K.; Jolly, C.M.; Aggarwal, D. Human aflatoxicosis in developing countries: A review of toxicology, exposure, potential health consequences, and interventions. Am. J. Clin. Nutr. 2004, 80, 1106-1122. [PubMed]

26. Gong, Y.Y.; Watson, S.; Routledge, M.N. Aflatoxin exposure and associated human health effects, a review of epidemiological studies. Food Saf. 2016, 4, 14-27. [CrossRef]

27. Eivazzadeh-Keihan, R.; Pashazadeh, P.; Hejazi, M.; de la Guardia, M.; Mokhtarzadeh, A. Recent advances in nanomaterial-mediated bio and immune sensors for detection of aflatoxin in food products. TrAC-Trend Anal. Chem. 2017, 87, 112-128. [CrossRef]

28. Iamanaka, B.T.; de Menezes, H.C.; Vicente, E.; Leite, R.S.F.; Taniwaki, M.H. Aflatoxigenic fungi and aflatoxins occurrence in sultanas and dried figs commercialized in Brazil. Food Control 2007, 18, 454-457. [CrossRef]

29. Ghali, R.; Hmaissia-khlifa, K.; Ghorbel, H.; Maaroufi, K.; Hedili, A. Incidence of aflatoxins, ochratoxin A and zearalenone in tunisian foods. Food Control 2008, 19, 921-924. [CrossRef]

30. IARC Working Group on the Evaluation of Carcinogenic Risk to Humans. Some traditional herbal medicines, some mycotoxins, naphthalene and styrene. IARC Monogr. Eval. Carcinog. Risks Hum. 2002, 82, 1-556.

31. Liu, G.; Qian, Y.; Zhang, P.; Dong, W.; Qi, Y.; Guo, H. Etiological role of alternaria alternata in human esophageal cancer. Chin. Med. J.-Peking 1992, 105, 394-400.

32. Man, Y.; Liang, G.; Li, A.; Pan, L. Analytical methods for the determination of Alternaria mycotoxins. Chromatographia 2017, 80, 9-22. [CrossRef]

33. Vejdovszky, K.; Warth, B.; Sulyok, M.; Marko, D. Non-synergistic cytotoxic effects of Fusarium and Alternaria toxin combinations in Caco-2 cells. Toxicol. Lett. 2016, 241, 1-8. [CrossRef] [PubMed]

34. Pahlke, G.; Tiessen, C.; Domnanich, K.; Kahle, N.; Groh, I.A.; Schreck, I.; Weiss, C.; Marko, D. Impact of Alternaria toxins on CYP1A1 expression in different human tumor cells and relevance for genotoxicity. Toxicol. Lett. 2016, 240, 93-104. [CrossRef] [PubMed]

35. Ostry, V. Alternaria mycotoxins: An overview of chemical characterization, producers, toxicity, analysis and occurrence in foodstuffs. World Mycotoxin J. 2008, 1, 175-188. [CrossRef]

36. Carrasco, L.; Vazquez, D. Differences in eukaryotic ribosomes detected by the selective action of an antibiotic. Biochim. Biophys. Acta 1973, 319, 209-215. [CrossRef]

37. Zhou, B.; Qiang, S. Environmental, genetic and cellular toxicity of tenuazonic acid isolated from Alternaira alternata. Afr. J. Biotechnol. 2008, 7, 1151-1156. 
38. Sauer, D.B.; Seitz, L.M.; Burroughs, R.; Mohr, H.E.; West, J.L.; Milleret, R.J.; Anthony, H.D. Toxicity of Alternaria metabolites found in weathered sorghum grain at harvest. J. Agric. Food. Chem. 1978, 26, 1380-1383. [CrossRef] [PubMed]

39. Meulenberg, E.P. Immunochemical methods for ochratoxin A detection: A review. Toxins 2012, 4, $244-266$. [CrossRef] [PubMed]

40. El Khoury, A.; Atoui, A. Ochratoxin A: General overview and actual molecular status. Toxins 2010, 2, 461-493. [CrossRef] [PubMed]

41. Chauhan, R.; Singh, J.; Sachdev, T.; Basu, T.; Malhotra, B.D. Recent advances in mycotoxins detection. Biosens. Bioelectron. 2016, 81, 532-545. [CrossRef] [PubMed]

42. Broekaert, N.; Devreese, M.; Demeyere, K.; Berthiller, F.; Michlmayr, H.; Varga, E.; Adam, G.; Meyer, E.; Croubels, S. Comparative in vitro cytotoxicity of modified deoxynivalenol on porcine intestinal epithelial cells. Food Chem. Toxicol. 2016, 95, 103-109. [CrossRef] [PubMed]

43. Bonnet, M.; Roux, J.; Mounien, L.; Dallaporta, M.; Troadec, J.D. Advances in Deoxynivalenol toxicity mechanisms: The brain as a target. Toxins 2012, 4, 1120-1138. [CrossRef] [PubMed]

44. Pestka, J.J. Deoxynivalenol: Toxicity, mechanisms and animal health risks. Anim. Feed Sci. Technol. 2007, 137, 283-298. [CrossRef]

45. Hueza, I.; Raspantini, P.; Raspantini, L.; Latorre, A.; Górniak, S. Zearalenone, an estrogenic mycotoxin, is an immunotoxic compound. Toxins 2014, 6, 1080-1095. [CrossRef] [PubMed]

46. Zinedine, A.; Soriano, J.M.; Moltó, J.C.; Mañes, J. Review on the toxicity, occurrence, metabolism, detoxification, regulations and intake of zearalenone: An oestrogenic mycotoxin. Food Chem. Toxicol. 2007, 45, 1-18. [CrossRef] [PubMed]

47. Puel, O.; Galtier, P.; Oswald, I. Biosynthesis and toxicological effects of Patulin. Toxins 2010, 2, 613-631. [CrossRef] [PubMed]

48. De Melo, F.T.; de Oliveira, I.M.; Greggio, S.; Dacosta, J.C.; Guecheva, T.N.; Saffi, J.; Henriques, J.A.P.; Rosa, R.M. DNA damage in organs of mice treated acutely with patulin, a known mycotoxin. Food Chem. Toxicol. 2012, 50, 3548-3555. [CrossRef] [PubMed]

49. Pitt, J.; Miller, J.D.; Trenholm, L. Mycotoxins in grain: Compounds other than aflatoxin. New Zeal. J. Crop. Hort. 1995, 23, 233-234.

50. Visconti, A.; Lattanzio, V.M.T.; Pascale, M.; Haidukowski, M. Analysis of T-2 and HT-2 toxins in cereal grains by immunoaffinity clean-up and liquid chromatography with fluorescence detection. J. Chromatogr. A 2005, 1075, 151-158. [CrossRef] [PubMed]

51. Sudakin, D.L. Trichothecenes in the environment: Relevance to human health. Toxicol. Lett. 2003, 143, 97-107. [CrossRef]

52. Anfossi, L.; Calderara, M.; Baggiani, C.; Giovannoli, C.; Arletti, E.; Giraudi, G. Development and application of a quantitative lateral flow immunoassay for fumonisins in maize. Anal. Chim. Acta 2010, 682, 104-109. [CrossRef] [PubMed]

53. Edite Bezerra da Rocha, M.; Freire, F.D.C.O.; Erlan Feitosa Maia, F.; Izabel Florindo Guedes, M.; Rondina, D. Mycotoxins and their effects on human and animal health. Food Control 2014, 36, 159-165. [CrossRef]

54. Harrison, L.R.; Colvin, B.M.; Greene, J.T.; Newman, L.E.; Cole, J.R., Jr. Pulmonary edema and hydrothorax in swine produced by fumonisin B1, a toxic metabolite of Fusarium moniliforme. J. Vet. Diagn. Investig. 1990, 2, 217-221. [CrossRef] [PubMed]

55. Xu, Y.; Xiong, L.; Li, Y.; Xiong, Y.; Tu, Z.; Fu, J.; Tang, X. Citrinin detection using phage-displayed anti-idiotypic single-domain antibody for antigen mimicry. Food Chem. 2015, 177, 97-101. [CrossRef] [PubMed]

56. Flajs, D.; Peraica, M. Toxicological properties of citrinin. Arh. Hig. Rada Toksikol. 2009, 60, 457-464. [CrossRef] [PubMed]

57. Bovdisova, I.; Zbynovska, K.; Kalafova, A.; Capcarova, M. Toxicological properties of mycotoxin Citrinin. J. Microbiol. Biotechnol. Food Sci. 2016, 5, 10-13. [CrossRef]

58. Dawod, M.; Arvin, N.E.; Kennedy, R.T. Recent advances in protein analysis by capillary and microchip electrophoresis. Analyst 2017, 142, 1847-1866. [CrossRef] [PubMed]

59. Wyatt Shields, C., IV; Reyes, C.D.; Lopez, G.P. Microfluidic cell sorting: A review of the advances in the separation of cells from debulking to rare cell isolation. Lab Chip 2015, 15, 1230-1249. [CrossRef] [PubMed]

60. Jung, W.; Han, J.; Choi, J.-W.; Ahn, C.H. Point-of-care testing (POCT) diagnostic systems using microfluidic lab-on-a-chip technologies. Microelectron. Eng. 2015, 132, 46-57. [CrossRef] 
61. Tetala, K.K.; Vijayalakshmi, M. A review on recent developments for biomolecule separation at analytical scale using microfluidic devices. Anal. Chim. Acta 2016, 906, 7-21. [CrossRef] [PubMed]

62. Whitesides, G.M. The origins and the future of microfluidics. Nature 2006, 442, 368-373. [CrossRef] [PubMed]

63. Qi, L.; Wang, Y.; Li, Y.; Zheng, G.; Li, C.; Su, H. Microfluidic aqueous two-phase extraction of bisphenol A using ionic liquid for high-performance liquid chromatography analysis. Anal. Bioanal. Chem. 2015, 407, 3617-3625. [CrossRef] [PubMed]

64. Pinto, I.F.; Caneira, C.R.F.; Soares, R.R.G.; Madaboosi, N.; Aires-Barros, M.R.; Conde, J.P.; Azevedo, A.M.; $\mathrm{Chu}, \mathrm{V}$. The application of microbeads to microfluidic systems for enhanced detection and purification of biomolecules. Methods 2017, 116, 112-124. [CrossRef] [PubMed]

65. Barbulovic-Nad, I.; Lucente, M.; Sun, Y.; Zhang, M.; Wheeler, A.R.; Bussmann, M. Bio-microarray fabrication techniques-A review. Crit. Rev. Biotechnol. 2006, 26, 237-259. [CrossRef] [PubMed]

66. Ren, K.; Zhou, J.; Wu, H. Materials for microfluidic chip fabrication. Acc. Chem. Res. 2013, 46, $2396-2406$. [CrossRef] [PubMed]

67. Sollier, E.; Murray, C.; Maoddi, P.; Di Carlo, D. Rapid prototyping polymers for microfluidic devices and high pressure injections. Lab Chip 2011, 11, 3752-3765. [CrossRef] [PubMed]

68. Shin, Y.; Perera, A.P.; Wong, C.C.; Park, M.K. Solid phase nucleic acid extraction technique in a microfluidic chip using a novel non-chaotropic agent: Dimethyl adipimidate. Lab Chip 2014, 14, 359-368. [CrossRef] [PubMed]

69. Xuefeng, Y.; Hong, S.; Zhaolun, F. A simplified microfabrication technology for production of glass microfluidic chips. Chin. J. Anal. Chem. 2003, 31, 116-119.

70. Chen, X.; Liu, C.; Xu, Z.; Pan, Y.; Liu, J.; Du, L. An effective PDMS microfluidic chip for chemiluminescence detection of cobalt (II) in water. Microsyst. Technol. 2013, 19, 99-103. [CrossRef]

71. Chen, X.Y.; Li, T.Y.; Zhang, S.; Yao, Z.; Chen, X.D.; Zheng, Y.; Liu, Y.L. Research on optimizing parameters of thermal bonding technique for PMMA microfluidic chip. Int. Polym. Proc. 2017, 32, 394-398. [CrossRef]

72. Metz, S.; Holzer, R.; Renaud, P. Polyimide-based microfluidic devices. Lab Chip 2001, 1, 29-34. [CrossRef] [PubMed]

73. Chen, X.; Hu, Z. An effective method for fabricating microchannels on the polycarbonate (PC) substrate with $\mathrm{CO}_{2}$ laser. Int. J. Adv. Manuf. Technol. 2017, 92, 1365-1370. [CrossRef]

74. Li, H.; Fan, Y.; Kodzius, R.; Foulds, I.G. Fabrication of polystyrene microfluidic devices using a pulsed $\mathrm{CO}_{2}$ laser system. Microsyst. Technol. 2012, 18, 373-379. [CrossRef]

75. Li, J.M.; Liu, C.; Qiao, H.C.; Zhu, L.Y.; Chen, G.; Dai, X.D. Hot embossing/bonding of a poly(ethylene terephthalate) (PET) microfluidic chip. J. Micromech. Microeng. 2008, 18, 015008. [CrossRef]

76. Swickrath, M.J.; Shenoy, S.; Mann, J.A.; Belcher, J.; Kovar, R.; Wnek, G.E. The design and fabrication of autonomous polymer-based surface tension-confined microfluidic platforms. Microfluid. Nanofluid. 2008, 4, 601-611. [CrossRef]

77. Nunes, P.S.; Ohlsson, P.D.; Ordeig, O.; Kutter, J.P. Cyclic olefin polymers: Emerging materials for lab-on-a-chip applications. Microfluid. Nanofluid. 2010, 9, 145-161. [CrossRef]

78. Ren, K.; Dai, W.; Zhou, J.; Su, J.; Wu, H. Whole-Teflon microfluidic chips. Proc. Natl. Acad. Sci. USA 2011, 108, 8162-8166. [CrossRef] [PubMed]

79. Yu, J.; Liu, Z.; Liu, Q.; Yuen, K.T.; Mak, A.F.T.; Yang, M.; Leung, P. A polyethylene glycol (PEG) microfluidic chip with nanostructures for bacteria rapid patterning and detection. Sens. Actuators A Phys. 2009, 154, 288-294. [CrossRef]

80. Liu, Z.-B.; Zhang, Y.; Yu, J.-J.; Mak, A.F.-T.; Li, Y.; Yang, M. A microfluidic chip with poly(ethylene glycol) hydrogel microarray on nanoporous alumina membrane for cell patterning and drug testing. Sens. Actuators B Chem. 2010, 143, 776-783. [CrossRef]

81. Abgrall, P.; Conedera, V.; Camon, H.; Gue, A.M.; Nguyen, N.T. SU-8 as a structural material for labs-on-chips and microelectromechanical systems. Electrophoresis 2007, 28, 4539-4551. [CrossRef] [PubMed]

82. Wägli, P.; Homsy, A.; de Rooij, N.F. Norland optical adhesive (NOA81) microchannels with adjustable wetting behavior and high chemical resistance against a range of mid-infrared-transparent organic solvents. Sens. Actuators B Chem. 2011, 156, 994-1001. [CrossRef]

83. Leclerc, E.; Furukawa, K.S.; Miyata, F.; Sakai, Y.; Ushida, T.; Fujii, T. Fabrication of microstructures in photosensitive biodegradable polymers for tissue engineering applications. Biomaterials 2004, 25, 4683-4690. [CrossRef] [PubMed] 
84. Martinez, A.W.; Phillips, S.T.; Whitesides, G.M.; Carrilho, E. Diagnostics for the developing world: Microfluidic paper-based analytical devices. Anal. Chem. 2010, 82, 3-10. [CrossRef] [PubMed]

85. Chabinyc, M.L.; Chiu, D.T.; McDonald, J.C.; Stroock, A.D.; Christian, J.F.; Karger, A.M.; Whitesides, G.M. An integrated fluorescence detection system in poly (dimethylsiloxane) for microfluidic applications. Anal. Chem. 2001, 73, 4491-4498. [CrossRef] [PubMed]

86. Hu, H.; Deng, Y.J.; Zou, J. Microfluidic smectite-polymer nanocomposite strip sensor for Aflatoxin detection. IEEE Sens. J. 2013, 13, 1835-1839. [CrossRef]

87. Shu, M.; Xu, Y.; Liu, X.; Li, Y.; He, Q.; Tu, Z.; Fu, J.; Gee, S.J.; Hammock, B.D. Anti-idiotypic nanobody-alkaline phosphatase fusion proteins: Development of a one-step competitive enzyme immunoassay for fumonisin B1 detection in cereal. Anal. Chim. Acta 2016, 924, 53-59. [CrossRef] [PubMed]

88. Xiao, H.; Clarke, J.R.; Marquardt, R.R.; Frohlich, A.A. Improved methods for conjugating selected mycotoxins to carrier proteins and dextran for immunoassays. J. Agric. Food. Chem. 1995, 43, 2092-2097. [CrossRef]

89. Peltomaa, R.; Benito-Peña, E.; Barderas, R.; Sauer, U.; González Andrade, M.; Moreno-Bondi, M.C. Microarray-based immunoassay with synthetic mimotopes for the detection of fumonisin B1. Anal. Chem. 2017, 89, 6216-6223. [CrossRef] [PubMed]

90. Ngundi, M.M.; Shriver-Lake, L.C.; Moore, M.H.; Lassman, M.E.; Ligler, F.S.; Taitt, C.R. Array biosensor for detection of Ochratoxin A in cereals and beverages. Anal. Chem. 2005, 77, 148-154. [CrossRef] [PubMed]

91. Ngundi, M.M.; Qadri, S.A.; Wallace, E.V.; Moore, M.H.; Lassman, M.E.; Shriver-Lake, L.C.; Ligler, F.S.; Taitt, C.R. Detection of Deoxynivalenol in foods and indoor air using an array biosensor. Environ. Sci. Technol. 2006, 40, 2352-2356. [CrossRef] [PubMed]

92. Wang, Y.; Liu, N.; Ning, B.; Liu, M.; Lv, Z.; Sun, Z.; Peng, Y.; Chen, C.; Li, J.; Gao, Z. Simultaneous and rapid detection of six different mycotoxins using an immunochip. Biosens. Bioelectron. 2012, 34, 44-50. [CrossRef] [PubMed]

93. Yang, Y.; Li, W.; Shen, P.; Liu, R.; Li, Y.; Xu, J.; Zheng, Q.; Zhang, Y.; Li, J.; Zheng, T. Aptamer fluorescence signal recovery screening for multiplex mycotoxins in cereal samples based on photonic crystal microsphere suspension array. Sens. Actuators B Chem. 2017, 248, 351-358. [CrossRef]

94. Tsukagoshi, K.; Jinno, N.; Nakajima, R. Development of a micro total analysis system incorporating chemiluminescence detection and application to detection of cancer markers. Anal. Chem. 2005, 77, 1684-1688. [CrossRef] [PubMed]

95. Baeyens, W.; Schulman, S.; Calokerinos, A.C.; Zhao, Y.; Campana, A.M.G.; Nakashima, K.; De Keukeleire, D. Chemiluminescence-based detection: Principles and analytical applications in flowing streams and in immunoassays. J. Pharmaceut. Biomed. 1998, 17, 941-953. [CrossRef]

96. Sauceda-Friebe, J.C.; Karsunke, X.Y.Z.; Vazac, S.; Biselli, S.; Niessner, R.; Knopp, D. Regenerable immuno-biochip for screening ochratoxin A in green coffee extract using an automated microarray chip reader with chemiluminescence detection. Anal. Chim. Acta 2011, 689, 234-242. [CrossRef] [PubMed]

97. Oswald, S.; Dietrich, R.; Märtlbauer, E.; Niessner, R.; Knopp, D. Microarray-based immunoassay for parallel quantification of multiple mycotoxins in oat. Oat 2017, 1536, 143-156.

98. Liu, R.; Huang, Y.; Ma, Y.; Jia, S.; Gao, M.; Li, J.; Zhang, H.; Xu, D.; Wu, M.; Chen, Y. Design and synthesis of target-responsive aptamer-cross-linked hydrogel for visual quantitative detection of Ochratoxin A. ACS Appl. Mater. Interface 2015, 7, 6982-6990. [CrossRef] [PubMed]

99. Ma, Y.; Mao, Y.; Huang, D.; He, Z.; Yan, J.; Tian, T.; Shi, Y.; Song, Y.; Li, X.; Zhu, Z.; Zhou, L.; Yang, C.J. Portable visual quantitative detection of aflatoxin B1 using a target-responsive hydrogel and a distance-readout microfluidic chip. Lab Chip 2016, 16, 3097-3104. [CrossRef] [PubMed]

100. Li, X.; Yang, F.; Wong, J.X.; Yu, H.-Z. Integrated smartphone-app-chip system for on-site ppb-level colorimetric quantitation of aflatoxins. Anal. Chem. 2017, 89, 8908-8916. [CrossRef] [PubMed]

101. Hervás, M.; López, M.A.; Escarpa, A. Electrochemical immunosensing on board microfluidic chip platforms. TrAC Trends Anal. Chem. 2012, 31, 109-128. [CrossRef]

102. Wang, H.; Meng, S.; Guo, K.; Liu, Y.; Yang, P.; Zhong, W.; Liu, B. Microfluidic immunosensor based on stable antibody-patterned surface in PMMA microchip. Electrochem. Commun. 2008, 10, 447-450. [CrossRef]

103. Piermarini, S.; Micheli, L.; Ammida, N.H.S.; Palleschi, G.; Moscone, D. Electrochemical immunosensor array using a 96-well screen-printed microplate for aflatoxin B1 detection. Biosens. Bioelectron. 2007, 22, 1434-1440. [CrossRef] [PubMed] 
104. Parker, C.O.; Lanyon, Y.H.; Manning, M.; Arrigan, D.W.; Tothill, I.E. Electrochemical immunochip sensor for aflatoxin M1 detection. Anal. Chem. 2009, 81, 5291-5298. [CrossRef] [PubMed]

105. Arévalo, F.J.; Granero, A.M.; Fernández, H.; Raba, J.; Zón, M.A. Citrinin (CIT) determination in rice samples using a micro fluidic electrochemical immunosensor. Talanta 2011, 83, 966-973. [CrossRef] [PubMed]

106. Olcer, Z.; Esen, E.; Muhammad, T.; Ersoy, A.; Budak, S.; Uludag, Y. Fast and sensitive detection of mycotoxins in wheat using microfluidics based Real-time Electrochemical Profiling. Biosens. Bioelectron. 2014, 62, 163-169. [CrossRef] [PubMed]

107. Uludag, Y.; Esen, E.; Kokturk, G.; Ozer, H.; Muhammad, T.; Olcer, Z.; Basegmez, H.I.O.; Simsek, S.; Barut, S.; Gok, M.Y. Lab-on-a-chip based biosensor for the real-time detection of aflatoxin. Talanta 2016, 160, 381-388. [CrossRef] [PubMed]

108. Hervas, M.; Lopez, M.A.; Escarpa, A. Electrochemical microfluidic chips coupled to magnetic bead-based ELISA to control allowable levels of zearalenone in baby foods using simplified calibration. Analyst 2009, 134, 2405-2411. [CrossRef] [PubMed]

109. Hervas, M.; Lopez, M.A.; Escarpa, A. Integrated electrokinetic magnetic bead-based electrochemical immunoassay on microfluidic chips for reliable control of permitted levels of zearalenone in infant foods. Analyst 2011, 136, 2131-2138. [CrossRef] [PubMed]

110. Panini, N.V.; Salinas, E.; Messina, G.A.; Raba, J. Modified paramagnetic beads in a microfluidic system for the determination of zearalenone in feedstuffs samples. Food Chem. 2011, 125, 791-796. [CrossRef]

111. Fernandez-Baldo, M.A.; Bertolino, F.A.; Fernandez, G.; Messina, G.A.; Sanz, M.I.; Raba, J. Determination of Ochratoxin A in apples contaminated with Aspergillus ochraceus by using a microfluidic competitive immunosensor with magnetic nanoparticles. Analyst 2011, 136, 2756-2762. [CrossRef] [PubMed]

112. Vistas, C.R.; Soares, S.S.; Rodrigues, R.M.; Chu, V.; Conde, J.P.; Ferreira, G.N. An amorphous silicon photodiode microfluidic chip to detect nanomolar quantities of HIV-1 virion infectivity factor. Analyst 2014, 139, 3709-3713. [CrossRef] [PubMed]

113. Caputo, D.; Cesare, G.D.; Dolci, L.S.; Mirasoli, M.; Nascetti, A.; Roda, A.; Scipinotti, R. Microfluidic chip with integrated a-Si:H photodiodes for chemiluminescence-based bioassays. IEEE Sens. J. 2013, 13, 2595-2602. [CrossRef]

114. Mirasoli, M.; Nascetti, A.; Caputo, D.; Zangheri, M.; Scipinotti, R.; Cevenini, L.; de Cesare, G.; Roda, A. Multiwell cartridge with integrated array of amorphous silicon photosensors for chemiluminescence detection: Development, characterization and comparison with cooled-CCD luminograph. Anal. Bioanal. Chem. 2014, 406, 5645-5656. [CrossRef] [PubMed]

115. Novo, P.; Moulas, G.; Prazeres, D.M.F.; Chu, V.; Conde, J.P. Detection of ochratoxin A in wine and beer by chemiluminescence-based ELISA in microfluidics with integrated photodiodes. Sens. Actuators B Chem. 2013, 176, 232-240. [CrossRef]

116. Soares, R.R.G.; Ramadas, D.; Chu, V.; Aires-Barros, M.R.; Conde, J.P.; Viana, A.S.; Cascalheira, A.C. An ultrarapid and regenerable microfluidic immunoassay coupled with integrated photosensors for point-of-use detection of ochratoxin A. Sens. Actuators B Chem. 2016, 235, 554-562. [CrossRef]

117. Soares, R.R.; Santos, D.R.; Chu, V.; Azevedo, A.M.; Aires-Barros, M.R.; Conde, J.P. A point-of-use microfluidic device with integrated photodetector array for immunoassay multiplexing: Detection of a panel of mycotoxins in multiple samples. Biosens. Bioelectron. 2017, 87, 823-831. [CrossRef] [PubMed]

118. Costantini, F.; Sberna, C.; Petrucci, G.; Reverberi, M.; Domenici, F.; Fanelli, C.; Manetti, C.; de Cesare, G.; DeRosa, M.; Nascetti, A.; Caputo, D. Aptamer-based sandwich assay for on chip detection of Ochratoxin A by an array of amorphous silicon photosensors. Sens. Actuators B Chem. 2016, 230, 31-39. [CrossRef]

119. Jiang, Y.; Wang, P.-C.; Locascio, L.E.; Lee, C.S. Integrated plastic microfluidic devices with ESI-MS for drug screening and residue analysis. Anal. Chem. 2001, 73, 2048-2053. [CrossRef] [PubMed]

120. Kussak, A.; Nilsson, C.A.; Andersson, B.; Langridge, J. Determination of aflatoxins in dust and urine by liquid chromatography/electrospray ionization tandem mass spectrometry. Rapid Commun. Mass Spectrom. 1995, 9, 1234-1237. [CrossRef] [PubMed]

121. Liu, H.-Y.; Lin, S.-L.; Chan, S.-A.; Lin, T.-Y.; Fuh, M.-R. Microfluidic chip-based nano-liquid chromatography tandem mass spectrometry for quantification of aflatoxins in peanut products. Talanta 2013, 113, 76-81. [CrossRef] [PubMed]

122. Li, Y.; Liu, X.; Lin, Z. Recent developments and applications of surface plasmon resonance biosensors for the detection of mycotoxins in foodstuffs. Food Chem. 2012, 132, 1549-1554. [CrossRef] 
123. Hodnik, V.; Anderluh, G. Toxin detection by surface plasmon resonance. Sensors 2009, 9, 1339-1354. [CrossRef] [PubMed]

124. Edupuganti, S.R.; Edupuganti, O.P.; O'Kennedy, R. Biological and synthetic binders for immunoassay and sensor-based detection: Generation and characterisation of an anti-AFB2 single-chain variable fragment (scFv). World Mycotoxin J. 2013, 6, 273-280. [CrossRef]

125. Edupuganti, S.R.; Edupuganti, O.P.; O'Kennedy, R. Generation of anti-zearalenone scFv and its incorporation into surface plasmon resonance-based assay for the detection of zearalenone in sorghum. Food Control 2013, 34, 668-674. [CrossRef]

126. Kadota, T.; Takezawa, Y.; Hirano, S.; Tajima, O.; Maragos, C.M.; Nakajima, T.; Tanaka, T.; Kamata, Y.; Sugita-Konishi, Y. Rapid detection of nivalenol and deoxynivalenol in wheat using surface plasmon resonance immunoassay. Anal. Chim. Acta 2010, 673, 173-178. [CrossRef] [PubMed]

127. Meneely, J.P.; Sulyok, M.; Baumgartner, S.; Krska, R.; Elliott, C.T. A rapid optical immunoassay for the screening of T-2 and HT-2 toxin in cereals and maize-based baby food. Talanta 2010, 81, 630-636. [CrossRef] [PubMed]

128. Meneely, J.P.; Quinn, J.G.; Flood, E.M.; Hajšlová, J.; Elliott, C.T. Simultaneous screening for T-2/HT-2 and deoxynivalenol in cereals using a surface plasmon resonance immunoassay. World Mycotoxin J. 2012, 5, 117-126. [CrossRef]

129. Pennacchio, A.; Ruggiero, G.; Staiano, M.; Piccialli, G.; Oliviero, G.; Lewkowicz, A.; Synak, A.; Bojarski, P.; D'Auria, S. A surface plasmon resonance based biochip for the detection of patulin toxin. Opt. Mater. 2014, 36, 1670-1675. [CrossRef]

130. Dorokhin, D.; Haasnoot, W.; Franssen, M.C.R.; Zuilhof, H.; Nielen, M.W.F. Imaging surface plasmon resonance for multiplex microassay sensing of mycotoxins. Anal. Bioanal. Chem. 2011, 400, 3005. [CrossRef] [PubMed]

131. Joshi, S.; Annida, R.M.; Zuilhof, H.; van Beek, T.A.; Nielen, M.W.F. Analysis of mycotoxins in beer using a portable nanostructured imaging surface plasmon resonance biosensor. J. Agric. Food Chem. 2016, 64, 8263-8271. [CrossRef] [PubMed]

132. Joshi, S.; Segarra-Fas, A.; Peters, J.; Zuilhof, H.; van Beek, T.A.; Nielen, M.W.F. Multiplex surface plasmon resonance biosensing and its transferability towards imaging nanoplasmonics for detection of mycotoxins in barley. Analyst 2016, 141, 1307-1318. [CrossRef] [PubMed]

133. Joshi, S.; Zuilhof, H.; van Beek, T.A.; Nielen, M.W.F. Biochip spray: Simplified coupling of surface plasmon resonance biosensing and mass spectrometry. Anal. Chem. 2017, 89, 1427-1432. [CrossRef] [PubMed]

134. Hu, W.; Chen, H.; Zhang, H.; He, G.; Li, X.; Zhang, X.; Liu, Y.; Li, C.M. Sensitive detection of multiple mycotoxins by SPRi with gold nanoparticles as signal amplification tags. J. Colloid Interface Sci. 2014, 431, 71-76. [CrossRef] [PubMed]

135. Karczmarczyk, A.; Reiner-Rozman, C.; Hageneder, S.; Dubiak-Szepietowska, M.; Dostálek, J.; Feller, K.-H. Fast and sensitive detection of ochratoxin A in red wine by nanoparticle-enhanced SPR. Anal. Chim. Acta 2016, 937, 143-150. [CrossRef] [PubMed]

136. Karczmarczyk, A.; Dubiak-Szepietowska, M.; Vorobii, M.; Rodriguez-Emmenegger, C.; Dostálek, J.; Feller, K.-H. Sensitive and rapid detection of aflatoxin M1 in milk utilizing enhanced SPR and p(HEMA) brushes. Biosens. Bioelectron. 2016, 81, 159-165. [CrossRef] [PubMed]

137. Park, J.H.; Kim, Y.-P.; Kim, I.-H.; Ko, S. Rapid detection of aflatoxin B 1 by a bifunctional protein crosslinker-based surface plasmon resonance biosensor. Food Control 2014, 36, 183-190. [CrossRef]

138. Zhu, Z.; Feng, M.; Zuo, L.; Zhu, Z.; Wang, F.; Chen, L.; Li, J.; Shan, G.; Luo, S.-Z. An aptamer based surface plasmon resonance biosensor for the detection of ochratoxin A in wine and peanut oil. Biosens. Bioelectron. 2015, 65, 320-326. [CrossRef] [PubMed]

139. Sun, L.; Wu, L.; Zhao, Q. Aptamer based surface plasmon resonance sensor for aflatoxin B1. Microchim. Acta 2017, 184, 2605-2610. [CrossRef]

140. Park, J.-H.; Byun, J.-Y.; Mun, H.; Shim, W.-B.; Shin, Y.-B.; Li, T.; Kim, M.-G. A regeneratable, label-free, localized surface plasmon resonance (LSPR) aptasensor for the detection of ochratoxin A. Biosens. Bioelectron. 2014, 59, 321-327. [CrossRef] [PubMed]

141. Bianco, M.; Sonato, A.; De Girolamo, A.; Pascale, M.; Romanato, F.; Rinaldi, R.; Arima, V. An aptamer-based SPR-polarization platform for high sensitive OTA detection. Sens. Actuators B Chem. 2017, 241, 314-320. [CrossRef] 
142. Choi, S.-W.; Chang, H.-J.; Lee, N.; Chun, H.S. A surface plasmon resonance sensor for the detection of deoxynivalenol using a molecularly imprinted polymer. Sensors 2011, 11, 8654-8664. [CrossRef] [PubMed]

143. Choi, S.-W.; Chang, H.-J.; Lee, N.; Kim, J.-H.; Chun, H.S. Detection of mycoestrogen zearalenone by a molecularly imprinted polypyrrole-based surface plasmon resonance (SPR) sensor. J. Agric. Food Chem. 2009, 57, 1113-1118. [CrossRef] [PubMed]

144. Atar, N.; Eren, T.; Yola, M.L. A molecular imprinted SPR biosensor for sensitive determination of citrinin in red yeast rice. Food Chem. 2015, 184, 7-11. [CrossRef] [PubMed]

145. Gupta, G.; Bhaskar, A.S.B.; Tripathi, B.K.; Pandey, P.; Boopathi, M.; Rao, P.V.L.; Singh, B.; Vijayaraghavan, R. Supersensitive detection of T-2 toxin by the in situ synthesized $\pi$-conjugated molecularly imprinted nanopatterns. An in situ investigation by surface plasmon resonance combined with electrochemistry. Biosens. Bioelectron. 2011, 26, 2534-2540. [CrossRef] [PubMed]

146. Wang, Y.; Yan, B.; Chen, L. SERS Tags: Novel optical nanoprobes for bioanalysis. Chem. Rev. 2013, 113, 1391-1428. [CrossRef] [PubMed]

147. Galarreta, B.C.; Tabatabaei, M.; Guieu, V.; Peyrin, E.; Lagugné-Labarthet, F. Microfluidic channel with embedded SERS 2D platform for the aptamer detection of ochratoxin A. Anal. Bioanal. Chem. 2013, 405, 1613-1621. [CrossRef] [PubMed]

148. Li, Q.; Lu, Z.; Tan, X.; Xiao, X.; Wang, P.; Wu, L.; Shao, K.; Yin, W.; Han, H. Ultrasensitive detection of aflatoxin B1 by SERS aptasensor based on exonuclease-assisted recycling amplification. Biosens. Bioelectron. 2017, 97, 59-64. [CrossRef] [PubMed]

149. Majer-Baranyi, K.; Székács, A.; Szendrő, I.; Kiss, A.; Adányi, N. Optical waveguide lightmode spectroscopy technique-based immunosensor development for deoxynivalenol determination in wheat samples. Eur. Food Res. Technol. 2011, 233, 1041-1047. [CrossRef]

150. Majer-Baranyi, K.; Zalán, Z.; Mörtl, M.; Juracsek, J.; Szendrő, I.; Székács, A.; Adányi, N. Optical waveguide lightmode spectroscopy technique-based immunosensor development for aflatoxin B1 determination in spice paprika samples. Food Chem. 2016, 211, 972-977. [CrossRef] [PubMed]

151. Adányi, N.; Levkovets, I.A.; Rodriguez-Gil, S.; Ronald, A.; Váradi, M.; Szendrő, I. Development of immunosensor based on OWLS technique for determining Aflatoxin B1 and Ochratoxin A. Biosens. Bioelectron. 2007, 22, 797-802. [CrossRef] [PubMed]

152. Pagkali, V.; Petrou, P.S.; Salapatas, A.; Makarona, E.; Peters, J.; Haasnoot, W.; Jobst, G.; Economou, A.; Misiakos, K.; Raptis, I. Detection of ochratoxin A in beer samples with a label-free monolithically integrated optoelectronic biosensor. J. Hazard. Mater. 2017, 323, 75-83. [CrossRef] [PubMed]

153. Mak, A.C.; Osterfeld, S.J.; Yu, H.; Wang, S.X.; Davis, R.W.; Jejelowo, O.A.; Pourmand, N. Sensitive giant magnetoresistive-based immunoassay for multiplex mycotoxin detection. Biosens. Bioelectron. 2010, 25, 1635-1639. [CrossRef] [PubMed]

(C) 2017 by the authors. Licensee MDPI, Basel, Switzerland. This article is an open access article distributed under the terms and conditions of the Creative Commons Attribution (CC BY) license (http://creativecommons.org/licenses/by/4.0/). 